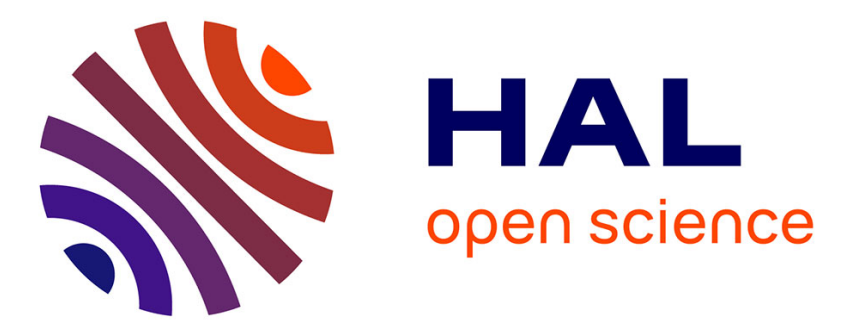

\title{
Direct determination of trace elements in powdered samples by in-cell isotope dilution femtosecond laser ablation ICPMS
}

B. Fernandez, Fanny Claverie, Christophe Pécheyran, J. Alexis, Olivier François Xavier Donard

\section{To cite this version:}

B. Fernandez, Fanny Claverie, Christophe Pécheyran, J. Alexis, Olivier François Xavier Donard. Direct determination of trace elements in powdered samples by in-cell isotope dilution femtosecond laser ablation ICPMS. Analytical Chemistry, 2008, vol. 80 ( $\left.\mathrm{n}^{\circ} 18\right)$, pp. 6981-6994. 10.1021/ac800862p . hal-01590322

\section{HAL Id: hal-01590322 \\ https://hal.science/hal-01590322}

Submitted on 10 Jan 2019

HAL is a multi-disciplinary open access archive for the deposit and dissemination of scientific research documents, whether they are published or not. The documents may come from teaching and research institutions in France or abroad, or from public or private research centers.
L'archive ouverte pluridisciplinaire HAL, est destinée au dépôt et à la diffusion de documents scientifiques de niveau recherche, publiés ou non, émanant des établissements d'enseignement et de recherche français ou étrangers, des laboratoires publics ou privés. 


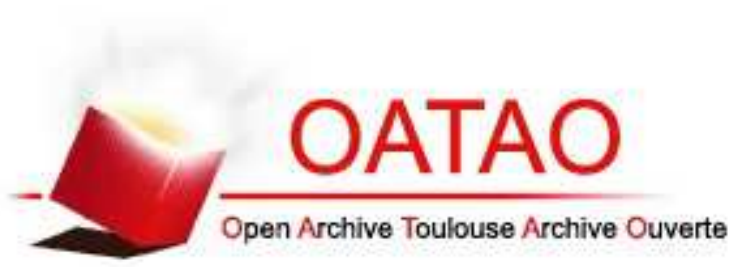

\section{Open Archive Toulouse Archive Ouverte (OATAO)}

OATAO is an open access repository that collects the work of Toulouse researchers and makes it freely available over the web where possible.

This is an author-deposited version published in: http://oatao.univ-toulouse.fr/ Eprints ID: 6494

To link to this article: DOI: $10.1021 / \mathrm{ac} 800862 \mathrm{p}$

http://dx.doi.org/10.1021/ac800862p

\section{To cite this version:}

Fernandez Garcia, Beatriz and Claverie, Fanny and Pécheyran, Christophe and Alexis, Joël and Donard, Olivier F.X Direct determination of trace elements in powdered samples by in-cell isotope dilution femtosecond laser ablation ICPMS. (2008) Analytical Chemistry, vol. 80 ( $\mathrm{n}^{\circ} 18$ ). pp. 6981-6994. ISSN 0003-2700

Any correspondence concerning this service should be sent to the repository administrator: staff-oatao@inp-toulouse.fr 


\title{
Direct Determination of Trace Elements in Powdered Samples by In-Cell Isotope Dilution Femtosecond Laser Ablation ICPMS
}

\author{
Beatriz Fernández, ${ }^{\dagger}$ Fanny Claverie, ${ }^{t, *}$ Christophe Pécheyran, ${ }^{*,+}$ Joel Alexis, ${ }^{\S}$ and \\ Olivier F. X. Donard ${ }^{\dagger}$
}

Laboratoire de Chimie Analytique Bio-Inorganique et Environnement (UMR CNRS 5254 IPREM), Université de Pau et des Pays de l'Adour, Hélioparc Pau-Pyrénées, 2 Avenue du Président Angot, 64053 Pau, France, Novalase SA, ZI de la Briqueterie, 6 Impasse du Bois de la Grange, 33610 Canejan, France, and Ecole Nationale d'Ingénieurs de Tarbes, 47 Avenue d'Azereix BP 1629, 65016 Tarbes, France

A method has been developed for the direct and simultaneous multielement determination of $\mathrm{Cu}, \mathrm{Zn}, \mathrm{Sn}$, and $\mathrm{Pb}$ in soil and sediment samples using femtosecond laser ablation inductively coupled plasma mass spectrometry (fs-LA-ICPMS) in combination with isotope dilution mass spectrometry (IDMS). The in-cell isotope dilution fs-LAICPMS method proposed in this work was based on the quasi-simultaneous ablation of the natural abundance sample and the isotopically enriched solid spike, which was performed using a high repetition rate laser and a fast scanning beam device in a combined manner. Both the sample preparation procedure and the total analysis time have been drastically reduced, in comparison with previous approaches, since a unique multielement isotopically enriched solid spike was employed to analyze different powdered samples. Numerous experimental parameters were carefully selected (e.g., carrier gas flow rate, inlet diameter of the ablation cell, sample translation speed, scanner speed, etc.) in order to ensure the complete mixing between the sample and the solid spike aerosols. The proposed in-cell fs-LA-ICP-IDMS method was tested for the analysis of two soil (CRM 142R, GBW07405) and two sediment (PACS-2, IAEA-405) reference materials, and the analysis of $\mathrm{Cu}, \mathrm{Zn}, \mathrm{Sn}$, and $\mathrm{Pb}$ yielded good agreement of usually not more than $10 \%$ deviation from the certified values and precisions of less than 15\% relative standard deviation. Furthermore, the concentrations were in agreement not only with the certified values but also with those obtained by ICP-IDMS after the microwave-assisted digestion of the solid samples, demonstrating therefore that in-cell fs-LA-ICP-IDMS opens the possibility for accurate and precise determinations of trace elements in powdered samples reducing the total sample preparation time to less than $5 \mathrm{~min}$. Additionally, scanning electron microscope measurements showed that the aerosol generated by in-cell fs-LA-ICP-IDMS predominantly consisted of linear agglomerates of small particles (in the order of few tens of nanometers) and a few large spherical particles with diameters below $225 \mathrm{~nm}$.
The combination of laser ablation (LA) technique and inductively coupled plasma mass spectrometry (ICPMS) is becoming one of the most powerful and versatile methods for trace element and isotopic analysis of solid materials. LA-ICPMS is an appealing method for the fast and sensitive analysis of different types of solids (e.g., geological, archeological, environmental, and biological matrixes), including microanalysis and depth profiling with excellent lateral and in-depth resolution. ${ }^{1-3}$ Nevertheless, LAICPMS is still far from being completely accepted as a universal method in analytical chemistry, mainly due to fractionation effects and the persistent lack of adequate reference materials for the wide variety of samples of interest.

The occurrence of nonstoichiometric response in the ICPMS transient signals, defined as elemental fractionation, often restricts the quantitative analysis to a few elements of identical fractionation behavior. ${ }^{4,5}$ During the last years, many causes of fractionation have been investigated in the different stages of LA-ICPMS and various methods have been explored to compensate, reduce, or eliminate fractionation effects. Although significant efforts are still underway to investigate the influence of parameters such as the laser wavelength, ${ }^{6}$ pulse duration, ${ }^{7-10}$ energy density, ${ }^{11}$ aerosol

* To whom correspondence should be addressed. Tel.: +33.559.407.757. Fax: +33.559.407.781. E-mail: Christophe.Pecheyran@univ-pau.fr.

${ }^{\dagger}$ Université de Pau et des Pays de l'Adour.

${ }^{*}$ Novalase SA.

$\$$ Ecole Nationale d'Ingénieurs de Tarbes.

(1) Durrant, S. F.; Ward, N. I. J. Anal. At. Spectrom. 2005, 20, 821-829.

(2) Günther, D.; Horn, I.; Hattendorf, B. Fresenius' J. Anal. Chem. 2000, 368, $4-14$.

(3) Günther, D.; Hattendorf, B. Trends Anal. Chem. 2005, 24, 255-265.

(4) Khun, H.-R.; Günther, D. Anal. Chem. 2003, 75, 747-753.

(5) Kroslakova, I.; Günther, D. J. Anal. At. Spectrom. 2007, 32, 51-62.

(6) Koch, J.; Wälle, M.; Pisonero, J.; Günther, D. J. Anal. At. Spectrom. 2006, 21, 932-940.

(7) Liu, C.; Mao, X. L.; Mao, S. S.; Zeng, X.; Greif, R.; Russo, R. E. Anal. Chem. 2004, 76, 379-383.

(8) González, J.; Dundas, S. H.; Liu, C. Y.; Mao, X.; Russo, R. E. J. Anal. At. Spectrom. 2006, 8, 778-784.

(9) Poitrasson, F.; Mao, X.; Mao, S.; Freydier, R.; Russo, R. E. Anal. Chem. 2003, 75, 6184-6190.

(10) Freydier, R.; Candaudap, F.; Poitrasson, F.; Arbouet, A.; Chatel, B.; Dupré, B. J. Anal. At. Spectrom. 2008, 23, 702-710.

(11) Koch, J.; von Bohlen, A.; Hergenröder, R.; Niemax, K. J. Anal. At. Spectrom. 2004, 19, 267-272.

(12) Koch, J.; Schlamp, S.; Rösgen, T.; Fliegel, D.; Günther, D. Spectrochim. Acta, Part B 2007, 62, 20-29. 
carrier gas, ${ }^{12,13}$ or ablation cell design, ${ }^{14,15}$ the capabilities of LAICPMS in terms of sensitivity, accuracy, and precision have continuously been improved due to instrumental advancements and the development of alternative calibration strategies. The current availability of robust and compact femtosecond (fs) laser systems has demonstrated its huge potential in terms of laser ablation efficiency, signal stability, sensitivity, and spatial resolution enhancement, as well as the suppression of elemental fractionation compared with nanosecond and picosecond laser sources. ${ }^{16,17}$

LA-ICPMS presents the advantages of direct solid sampling without dissolution and dilution of samples, such as the considerably shorter time required for sample preparation, higher sensitivity due to the absence of dilution, and reduced risk of sample contamination and analyte loss. In addition, for the analysis of solids in the form of powders, dust particulates, or other loose solid materials, LA-ICPMS can be used in combination with isotope dilution mass spectrometry (IDMS). IDMS is internationally regarded as a reference or primary method of analysis and, therefore, is widely used in different fields for obtaining accurate analytical results. ${ }^{18,19}$ In contrast to other calibration strategies, if a homogeneous distribution of both isotopically enriched spike and analyte (isotopic mixing) is achieved, the analytical result is not affected by signal drifts, matrix effects, or analyte losses. Thus, the application of isotope dilution in LA-ICPMS can correct for some common fractionation and matrix effects that cannot be controlled using other calibration procedures..$^{20,21}$

So far, the combination of LA-ICPMS and the isotope dilution technique has been investigated for the direct determination of trace elements in a wide variety of solid samples (e.g., soils, coals, sediments, mosses, road dusts, hair samples, petroleum products, etc.) using two different quantification methodologies. In order to overcome the quantification problem, Becker et al. ${ }^{22,23}$ proposed a special arrangement for online solution-based calibration. Online isotope dilution analysis was performed during the laser ablation of the sample by introducing a dry aerosol of a nebulized isotopically enriched spike solution into the ablation chamber. Such methodology is only able to correct for errors derived from the detection step and not for those derived from the ablation processes. A different quantification methodology based on the addition of the corresponding isotope-enriched spike solutions to the powdered sample, and the subsequent drying and pressing of the isotope-diluted sample, has been widely investigated by

(13) Koch, J.; Wälle, M.; Schlamp, S.; Rösgen, T.; Günther, D. Spectrochim. Acta, Part B 2008, 63, 37-41.

(14) Pisonero, J.; Fliegel, D.; Günther, D. J. Anal. At. Spectrom. 2006, 21, 922931.

(15) García, C. C.; Lindner, H.; Niemax, K. Spectrochim. Acta, Part B 2007, $62,13-19$.

(16) Koch, J.; Günther, D. Anal. Bioanal. Chem. 2007, 387, 149-153.

(17) Fernández, B.; Claverie, F.; Pécheyran, C.; Donard, O. F. X. Trends Anal. Chem. 2007, 26, 951-966.

(18) Heumann, K. G. Anal. Bioanal. Chem. 2004, 378, 318-329.

(19) Rodriguez-Gonzalez, P.; Marchante-Gayon, J. M.; García-Alonso, J. I.; SanzMedel, A. Spectrochim. Acta, Part B 2005, 60, 151-207.

(20) Tibi, M.; Heumann, K. G. Anal. Bioanal. Chem. 2003, 377, 126-131.

(21) Boulyga, S. F.; Tibi, M.; Heumann, K. G. Anal. Bioanal. Chem. 2004, 378, 342-347.

(22) Becker, J. S.; Pickhardt, C.; Pompe, W. Int. J. Mass Spectrom. 2004, 237, 13-17.

(23) Pickhardt, C.; Izmer, A. V.; Zoriy, M. V.; Schaumlöffel, D.; Becker, J. S. Int. J. Mass Spectrom. 2006, 248, 136-141.
Heumann et al. ${ }^{24-27}$ This methodology allows the matrix-matched quantification of elemental concentrations without any external standard correcting for all signal variations during the analysis, either derived from the instrumental drift or varying mass ablation rates. Nevertheless, the required addition, homogenization, and drying of the liquid spike solutions to each sample of interest increase considerably the total analysis time, particularly when a large number of samples have to be analyzed. To overcome the tedious synthesis process with the isotope-enriched spike solutions, an alternative sample preparation strategy has been recently proposed by Fernández et $\mathrm{al}^{28}$ The direct and simultaneous determination of trace elements in soil and sediment samples was accomplished by fs-LA-ICP-IDMS with the development of a solidspiking sample preparation procedure based on the synthesis of a unique isotopically enriched solid spike and the preparation of isotope-diluted blend pellets for each sample of interest.

This work presents the development of a new isotope dilution quantification methodology for the accurate, precise, and fast determination of trace elements in powdered samples using fsLA-ICPMS. The proposed in-cell isotope dilution LA-ICPMS method is based on the quasi-simultaneous ablation of the natural abundance sample and an isotopically enriched solid spike. Incell isotope dilution analysis with LA-ICPMS is possible only because the femtosecond laser ablation system used combines a laser source that can operate at high repetition rate with a fast scanning beam device that allows the movement of the laser beam by the scanner and the sample in the combined manner. The total analysis time is drastically reduced by the use of a unique multielemental isotopically enriched solid spike, which showed a satisfactory stability over a period of one year. The in-cell fs-LAICP-IDMS method was employed to analyze two soil (CRM 142R, GBW-07405) and two sediment (PACS-2, IAEA-405) reference materials, and the results obtained were compared not only with the certified values but also with those obtained by a conventional ICP-IDMS analysis after the microwave-assisted digestion of the samples. In addition, the particle size distribution of the lasergenerated aerosol was determined using low-pressure impaction, and collected aerosol particles were analyzed by scanning electron microscopy (SEM) in order to investigate the particle size and structure of the aerosols.

\section{EXPERIMENTAL SECTION}

Samples, Standards, and Reagents. Four certified reference materials (CRMs) were investigated to demonstrate the applicability of the proposed in-cell fs-LA-ICP-IDMS method to the direct analysis of trace elements in different types of powdered samples: CRM 142R (trace elements in a light sandy soil; particle size below $90 \mu \mathrm{m})$ from the Institute for Reference Materials and Measurements-IRMM (Geel, Belgium), GBW-07405 (yellow-red soil) from the Institute of Geophysical and Geochemical Exploration-IGGE (Hebei, China), PACS-2 (marine sediment reference material for

(24) Boulyga, S. F.; Heumann, K. G. Anal. Bioanal. Chem. 2005, 383, 442447.

(25) Boulyga, S. F.; Heumann, K. G. Int. J. Mass Spectrom. 2005, 242, 291296.

(26) Tibi, M.; Heumann, K. G. J. Anal. At. Spectrom. 2003, 18, 1076-1081.

(27) Boulyga, S. F.; Heilmann, J.; Heumann, K. G. Anal. Bioanal. Chem. 2005, 382, 1808-1814.

(28) Fernández, B.; Claverie, F.; Pécheyran, C.; Donard, O. F. X. J. Anal. At. Spectrom. 2008, 23, 367-377. 
trace metals and other constituents) from the Institute for National Measurement Standards-INMS (Ontario, Canada), and IAEA-405 (trace elements and methylmercury in estuarine sediment; particle size below $120 \mu \mathrm{m}$ ) from the International Atomic Energy AgencyIAEA (Vienna, Austria). The uncertainty values of the certified concentrations correspond to a $95 \%$ confidence interval. In all cases, the samples were handled according to the instructions for use given in the corresponding certificates, and pellets of 3 $\mathrm{mm}$ in diameter were prepared in a laboratory press $(0.5$ tons for $4 \mathrm{~min}$ ) for in-cell fs-LA-ICP-IDMS analyses.

Gallium $\left(1000 \mu \mathrm{g} \mathrm{mL}^{-1}\right)$, antimony $\left(1000 \mu \mathrm{g} \mathrm{mL}^{-1}\right)$, thallium $\left(1000 \mu \mathrm{g} \mathrm{mL}^{-1}\right)$, and tin $\left(100 \mu \mathrm{g} \mathrm{mL}^{-1}\right)$ standard solutions were obtained from SPEX CertiPrep Ltd. (Middlesex, UK). The multielemental standard solution CCS-6 $\left(100 \mu \mathrm{g} \mathrm{mL}{ }^{-1} \mathrm{Ag}, \mathrm{Cd}, \mathrm{Co}\right.$, $\mathrm{Cr}, \mathrm{Cu}, \mathrm{Fe}, \mathrm{Hg}, \mathrm{Mn}, \mathrm{Ni}, \mathrm{Pb}, \mathrm{Tl}, \mathrm{V}$, and $\mathrm{Zn}$ ) was prepared from Custom-Grade multielement solutions supplied by Inorganic Ventures Inc. (Lakewood, NJ). Ultrapure water was obtained from a Milli-Q system (18.2 M $\Omega$, Millipore), and Instra-Analyzed grade nitric and hydrochloric acids were purchased from J. T. Baker (Phillipsburg, NJ).

Spike Solutions. Enriched isotopes of ${ }^{65} \mathrm{Cu}(\mathrm{CuO}),{ }^{66} \mathrm{Zn}$ $(\mathrm{ZnO}),{ }^{119} \mathrm{Sn}\left(\mathrm{SnO}_{2}\right)$, and ${ }^{207} \mathrm{~Pb}\left(\mathrm{PbCO}_{3}\right)$ were purchased from SCP Sciences (Courtaboeuf Cedex, France). Spike solutions of ${ }^{65} \mathrm{Cu},{ }^{66} \mathrm{Zn}$, and ${ }^{207} \mathrm{~Pb}$ were prepared by dissolution of an accurately weighed amount of the solid enriched isotopes in nitric acid. The spike solution of ${ }^{119} \mathrm{Sn}$ was prepared by acid digestion of an accurately weighed amount of ${ }^{119} \mathrm{Sn}$-enriched $\mathrm{SnO}_{2}$ using a Multiwave 3000 microwave system (Anton Paar $\mathrm{GmbH}$ ) with addition of hydrochloric and nitric acid $(3: 1 \mathrm{w} / \mathrm{w})$. Isotopeenriched spike solutions for the preparation of the multielemental isotopically enriched solid spike were prepared from the corresponding stock solutions by dilution with Milli-Q water and acidifying with Instra-Analyzed grade nitric acid. The isotopic composition of the spike solutions was determined by ICPMS with corrections for mass discrimination by measuring corresponding standard solutions of natural isotopic composition. The elemental concentrations were analyzed by reverse ICP-IDMS and found to be $885.6 \pm 4.3 \mu \mathrm{g} \mathrm{g}^{-1}$ for $\mathrm{Cu}, 298.0 \pm 4.3 \mu \mathrm{g} \mathrm{g}^{-1}$ for $\mathrm{Zn}, 59.015 \pm$ $0.063 \mu \mathrm{g} \mathrm{g}^{-1}$ for $\mathrm{Sn}$, and $368.18 \pm 0.36 \mu \mathrm{g} \mathrm{g}^{-1}$ for $\mathrm{Pb}$. More detailed information on the used spike solutions is presented in previous publication. ${ }^{28}$

Multielement Isotopically Enriched Solid Spike. A unique synthesis process with the isotope-enriched spike solutions was required using the proposed in-cell isotope dilution fs-LA-ICPMS method, and thus, the most time-consuming stage of the analysis was reduced in a significant way. The certified reference material CRM 142R was selected as the solid matrix for the preparation of the isotopically enriched solid spike due to its low concentration values for the elements of interest $(\mathrm{Cu}, \mathrm{Zn}, \mathrm{Sn}, \mathrm{Pb})$. Approximately $2.50 \mathrm{~g}$ of the powder was weighed, and appropriate amounts of the spike solutions of ${ }^{65} \mathrm{Cu},{ }^{66} \mathrm{Zn}$, ${ }^{119} \mathrm{Sn}$, and ${ }^{207} \mathrm{~Pb}$ were directly added to the solid. The amount of added spikes was chosen to be in the range of an optimum analyte/spike ratio with respect to the error multiplication factor that influences the precision of IDMS results. ${ }^{19,29}$ In the present study, the isotopically enriched solid spike was used to analyze four different reference materials,

(29) Heumann, K. G. In Inorganic Mass Spectrometry; Adams, F., Gijbels, R., van Grieken, R., Eds.; Wiley: New York, 1988. so the amount of added spike solutions was selected to obtain the synthesized solid spike in an optimum analyte/spike ratio for all samples when mixing the sample and the solid spike aerosols in a 1:1 proportion in the ablation cell. However, it should be stressed that even variations up to more than 10 times the 1:1 proportion would lead to optimum analyte/spike ratios according to the random error propagation factor for each of the elements in the four CRMs. The homogenization of the spike solutions with the soil CRM 142R was simply achieved by manual shaking of the resulting slurry (a total volume of $6.2 \mathrm{~mL}$ ) until a homogeneous suspension was obtained. After drying at $90{ }^{\circ} \mathrm{C}$ for $6 \mathrm{~h}$ in a laminar flow clean bench using a DigiPREP Classic System (SCP Sciences), the isotopically enriched solid spike was ground in an agate mortar for 5 min until a fine homogeneous powder was obtained. Pellets of $3 \mathrm{~mm}$ in diameter were directly prepared in a laboratory press (without a pellet binder) for in-cell fs-LA-ICPIDMS analyses.

The elemental concentrations of both the isotopically enriched solid spike and the certified reference materials were calculated by conventional ICP-IDMS analysis after the microwave-assisted digestion of the samples. The isotopic abundances of the solid spike were calculated by ICPMS from a digested aliquot, and the elemental concentrations were determined by reverse isotope dilution analysis using natural abundance standards, which were added before digestion and found to be $324.3 \pm 1.8 \mu \mathrm{g} \mathrm{g}^{-1}$ for $\mathrm{Cu}, 399.4 \pm 2.1 \mu \mathrm{g} \mathrm{g}^{-1}$ for $\mathrm{Zn}, 8.992 \pm 0.024 \mu \mathrm{g} \mathrm{g}^{-1}$ for Sn, and $304.00 \pm 0.98 \mu \mathrm{g} \mathrm{g}^{-1}$ for $\mathrm{Pb}$. More detailed information on the analysis of CRMs by ICP-IDMS and the used isotopically enriched solid spike are presented in previous publication. ${ }^{28}$

In order to demonstrate that the synthesized isotopically enriched solid spike can be used over a large time scale for the analysis of different powdered samples, the study of the solid spike stability was carried out from December 2006 to December 2007. The isotopic composition of the solid spike was determined by fs-LA-ICPMS, performing the mass bias correction by the measurement of natural abundance isotope ratios in nonspiked pellets of the reference material CRM 142R for $\mathrm{Cu}, \mathrm{Zn}$, and $\mathrm{Sn}$ and by the continuous nebulization of a $\mathrm{Tl}$ standard solution for the correction of the $\mathrm{Pb}$ isotope ratios. The laser beam was focused onto the sample surface, and the $2 \mathrm{D}$ scanning ablation mode was selected for the analysis (ablated surface $100 \mu \mathrm{m} \times 1 \mathrm{~mm}$, scanner speed $2.0 \mathrm{~mm} \mathrm{~s}^{-1}$, and sample translation speed $10 \mu \mathrm{m} \mathrm{s}^{-1}$ ). Figure 1 shows the stability of the isotopically enriched solid spike observed throughout one year, given as the abundance of the enriched isotope in percentage. The isotopic abundances corresponding to December 2006 (date of the solid spike synthesis) were obtained both by fs-LA-ICPMS and by conventional nebulization ICPMS following the microwave-assisted digestion of the solid spike (denoted as December $06^{\star}$ ). As can be seen in Figure 1 , ICPMS reference values were compared with those obtained by fs-LA-ICPMS from December 2006 to December 2007, and no significant changes on the isotopic composition of the solid spike $\left({ }^{65} \mathrm{Cu},{ }^{66} \mathrm{Zn},{ }^{119} \mathrm{Sn},{ }^{207} \mathrm{~Pb}\right)$ were observed over a period of one year.

Instrumentation. An X Series II quadrupole ICPMS (Thermo Fischer Scientific, Winsford, UK) was used under the optimized conditions listed in Table 1. For laser ablation analyses, the Alfamet femtosecond laser system (Novalase SA, Canejan, France) 


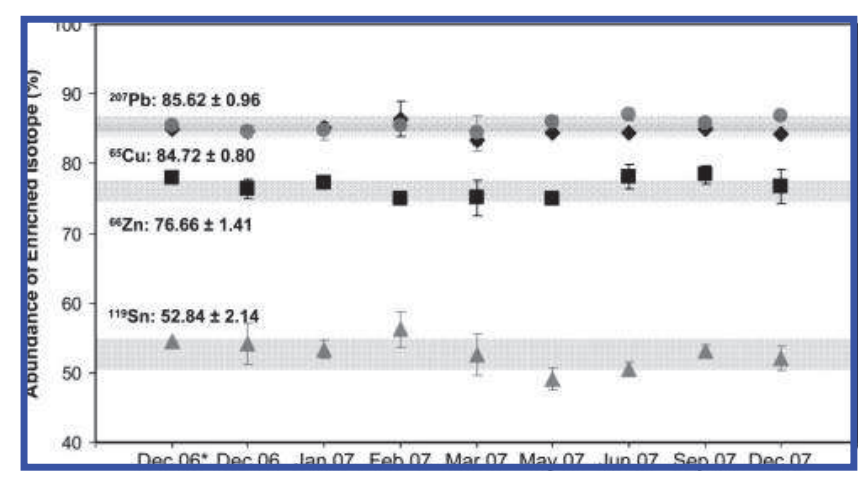

Figure 1. Stability of the multielement isotopically enriched solid spike over time determined by fs-LA-ICPMS. Measurements carried out in December 2006 (Dec.06*) were determined by ICPMS. Standard deviation values are calculated from the mean of six analyses.

\section{Table 1. Operating Conditions of the ICPMS and Laser Ablation Systems}

\section{ICPMS}

X Series II Quadrupole (Thermo Fisher Scientific)

argon flow rates

plasma gas auxiliary gas nebulization gas cones material torch dwell time isotopes

14.0 $\mathrm{L} \mathrm{min}^{-1}$

$0.80 \mathrm{~L} \mathrm{~min}^{-1}$

$0.70 \mathrm{~L} \mathrm{~min}^{-1}$

$\mathrm{Ni}$ (Xt configuration)

dual-mode introduction (Thermo Fisher)

$10 \mathrm{~ms}$

${ }^{63} \mathrm{Cu},{ }^{65} \mathrm{Cu},{ }^{64} \mathrm{Zn},{ }^{66} \mathrm{Zn},{ }^{68} \mathrm{Zn},{ }^{69} \mathrm{Ga},{ }^{71} \mathrm{Ga},{ }^{118} \mathrm{Sn}$, ${ }^{119} \mathrm{Sn},{ }^{120} \mathrm{Sn},{ }^{121} \mathrm{Sb},{ }^{123} \mathrm{Sb},{ }^{203} \mathrm{Tl},{ }^{205} \mathrm{Tl}$, ${ }^{206} \mathrm{~Pb},{ }^{207} \mathrm{~Pb},{ }^{208} \mathrm{~Pb}$

\begin{tabular}{ll}
\multicolumn{1}{c}{ laser ablation system } & ALFAMET (Novalase SA) \\
laser source crystal & Yb:KGW \\
wavelength & $1030 \mathrm{~nm}$ \\
pulse duration & $360 \mathrm{fs}$ \\
pulse energy & $30 \mu \mathrm{J}$ \\
repetition rate & $10000 \mathrm{~Hz}$ \\
spot diameter & $17 \mu \mathrm{m}$ \\
fluence & $19 \mathrm{~J} \mathrm{~cm}^{-2}$ \\
laser focus & on sample surface \\
scanner speed (laser on) & $200 \mathrm{~mm} \mathrm{~s} \mathrm{sm} \mathrm{s}^{-1}$ \\
scanner speed (laser off) & $100-500 \mathrm{~mm} \mathrm{~s}^{-1}$ \\
sample translation speed & $5 \mu \mathrm{m} \mathrm{s}$ s $^{-1}$ \\
carrier gas flow rate (He) & $0.57-0.87 \mathrm{~L} \mathrm{~min}^{-1}$
\end{tabular}

was employed. The laser source is fitted with a diode-pumped $\mathrm{Yb}: \mathrm{KGW}$ crystal delivering 360 -fs pulses at an IR wavelength of $1030 \mathrm{~nm}$, as described in Table 1. The laser source operates at high repetition rate $(1-10000 \mathrm{~Hz})$ and low energy $(<100 \mu \mathrm{J}$ pulse $^{-1}$ at $10 \mathrm{kHz}$ ), which represents a new approach in analytical applications where high energy and low repetition rate are commonly employed. The laser beam is focused with a $50-\mathrm{mm}$ objective, and it can be rapidly moved with high repositioning precision owing to a galvanometric scanning module fitted to the optical line. The inlet of the ablation cell could optionally be equipped with nozzles of 0.5 - and 0.25 -mm diameter to modify the in-cell flow conditions (original inlet diameter $1.0 \mathrm{~mm}$ ). Further details of the applied laser ablation system are described elsewhere. ${ }^{28,30,31}$

(30) Pécheyran, C.; Cany, S.; Chabassier, P.; Mottay, E.; Donard, O. F. X. J. Phys., Conf. Ser. 2007, 59, 112-117.
The LA-ICPMS coupling was carried out with the dual-mode sample introduction kit for gas chromatography from Thermo Fisher Scientific. The laser-generated aerosol is transported through an antistatic tube of 4-mm external diameter and 2.5-mm internal diameter (Legris SA) into the ICP torch by the He carrier gas of the ablation cell. A cyclonic chamber was inserted at the outlet line of the ablation cell to obtain a more homogeneous distribution of the aerosol and, therefore, to improve the precision of isotope ratios measurement. The analysis of natural abundance samples was performed by fs-LA-ICPMS at high repetition rate $(10 \mathrm{kHz})$ with and without the cyclonic chamber, and the use of the stabilizer device was found to improve the precision of all the isotope ratios investigated, especially for ${ }^{118} \mathrm{Sn} /{ }^{119} \mathrm{Sn}$ in which the precision was improved in some materials from 17 to $0.6 \%$. The interface consists of a two-inlet torch mixing the laser-generated aerosol together with a liquid aerosol (nebulized by means of a pneumatic concentric nebulizer) before introduction into the plasma. ${ }^{32,33}$ This dual-flow introduction system enables a complete and easy optimization of the LA-ICPMS coupling when nebulizing a $1 \mathrm{ng} \mathrm{g}{ }^{-1}$ solution of the elements employed for tuning. Furthermore, during laser ablation analyses, the plasma was kept under wet conditions by the continuous nebulization of a $\mathrm{Ga}, \mathrm{Sb}$, and $\mathrm{Tl}$ standards solution, which is used to calculate the mass bias factor for the measurement of $\mathrm{Cu}, \mathrm{Zn}, \mathrm{Sn}$, and $\mathrm{Pb}$ isotope ratios (Ga for $\mathrm{Cu}$ and $\mathrm{Zn}, \mathrm{Sb}$ for $\mathrm{Sn}$, and $\mathrm{Tl}$ for $\mathrm{Pb}$ ). A Sartorius (Goettingen, Germany) model BP211D analytical balance with a precision of $10^{-5} \mathrm{~g}$ was used for all weighing.

The particle size distribution of the laser-generated aerosol was measured using a 12-stage electrical low-pressure impactor (Elpi, Dekati Ltd.) designed for deposition of particles in a size range between 7-nm and $10-\mu \mathrm{m}$ aerodynamic diameter. Additionally, the laser-generated aerosol particles were collected on filters and analyzed by scanning electron microscopy (JEOL JSM-7000F field emission scanning electron microscope, JEOL Ltd.) in order to obtain information about particle size and structure.

Laser Ablation Strategy for In-Cell fs-LA-ICP-IDMS Analysis. The aim of the present work was the development of an incell isotope dilution fs-LA-ICPMS method for the direct and simultaneous determination of trace elements in powdered samples. The proposed method is based on the quasi-simultaneous analysis of two pellets that are placed together in the ablation cell: one corresponding to the natural abundance sample and the other to the isotopically enriched solid spike. Complete mixing between the sample and the solid spike aerosols is necessary to achieve the isotopic mixing and, therefore, to obtain accurate and precise analytical results. For in-cell isotope dilution analysis with LAICPMS, the Alfamet femtosecond laser system was employed due to its unique features: the laser source can operate at high repetition rate (up to $10 \mathrm{kHz}$ ) and the fast beam scanning system allows the movement of the laser beam by the scanner and the sample in the combined manner. ${ }^{28,31,34}$ Although the low-energy laser source implies the use of a narrow laser beam and the limited

(31) Ballihaut, G.; Claverie, F.; Pécheyran, C.; Monicou, S.; Grimaud, R.; Lobinski, R. Anal. Chem. 2007, 79, 6874-6880.

(32) Ballihaut, G.; Tastet, L.; Pécheyran, C.; Bouyssiere, B.; Donard, O. F. X.; Grimaud, R.; Lobinski, R. J. Anal. At. Spectrom. 2005, 20, 493-499.

(33) Barats, A.; Pécheyran, C.; Amouroux, D.; Dubascoux, S.; Chauvaud, L.; Donard, O. F. X. Anal. Bioanal. Chem. 2007, 387, 1131-1140.

(34) Donard, O. F. X.; Pécheyran, C.; Cany, S.; Chabassier, P. Direct Analysis Laser Machine. International Application PCT/FR2006/050298. 


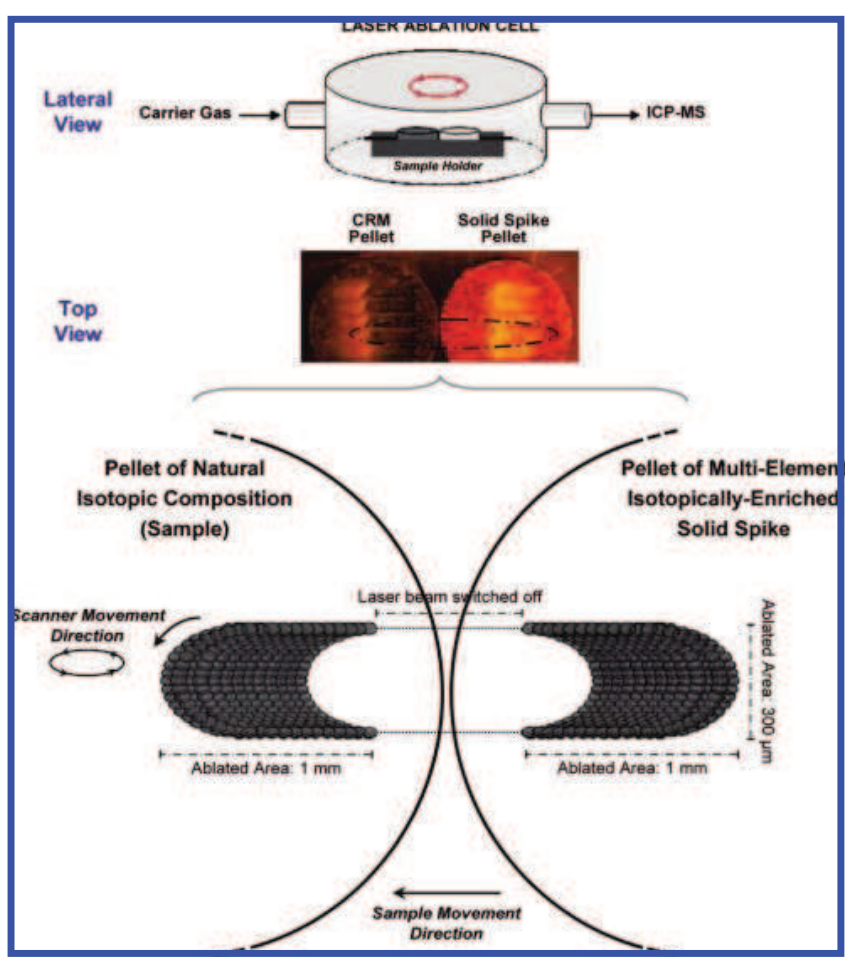

Figure 2. Schematic of laser ablation strategy for in-cell fs-LA-ICPIDMS analysis.

ablated area appears as a limiting factor in order to compensate for sample inhomogeneity, this drawback can be overcome by combining the fast beam scanning system and the high repetition rate of the laser. Using the crater ablation mode, the ablation of the sample is carried out at a fixed position whereas the translational sampling (2D scanning mode) is a dynamic ablation where the laser beam and the sample are continuously displaced at a constant rate resulting in a larger ablated area. Small craters corresponding to the laser beam spot size $(17 \mu \mathrm{m})$ are repeated in such a way that they can be overlapped while the beam and the sample are continuously displaced at constant rates, and therefore, the 2D scanning ablation mode reduces the effect of sample inhomogeneities in comparison with the crater mode.

Figure 2 shows the trajectory followed by the laser beam in the in-cell fs-LA-ICP-IDMS analysis. The laser ablates alternatively the pellet of the natural abundance sample and the pellet of the isotopically enriched solid spike describing an elliptical movement between the two pellets (2D elliptical ablation). For each trajectory, the ablated area in both pellets corresponds to a semicircle and between the two semicircles the laser beam is switched off. In order to explain more in detail the complex ablation strategy used, the elliptical movement followed by the laser beam can be divided in four different stages: (i) the laser beam is switched on and describes a semicircle movement in the sample pellet; (ii) the laser beam is switched off and follows a linear trajectory from the sample pellet to the solid spike pellet; (iii) the laser beam is switched on and describes a semicircle movement in the solid spike pellet; and (iv) the laser beam is switched off and follows a linear trajectory from the solid spike pellet to the sample pellet. Both the laser beam and the pellets are continuously moving at a constant rate, and the overlap of semicircles in each pellet results in a large and well-defined ablated area. The distance selected between two semicircles was $3.5 \mathrm{~mm}$, and the ablated area on the pellets' surface at the end of the analysis can be observed in Figure $2(300 \mu \mathrm{m} \times 1 \mathrm{~mm}$ for each pellet). Combining the fast beam scanning system and the high repetition rate of the laser $(10 \mathrm{kHz})$, it was possible to move the laser beam from one pellet to the other in a very short period of time (in the range of 15-150 $\mathrm{ms}$ ), which is a fundamental requirement to ensure complete mixing between the sample and the solid spike aerosols. In order to ensure the same focalization conditions, in-cell fs-LA-ICP-IDMS analyses were always performed on a not previously ablated zone of the pellets. In addition, in order to ensure that the laser beam was focused onto the samples' surface with the same focalization conditions for both pellets, a sample holder was developed. Such holder, especially designed in our case for 3-mm pellets, allows the analysis of two pellets with different thicknesses since it allows the adjustment of the samples on the same level by using metallic supports.

\section{RESULTS AND DISCUSSION}

Isotope Ratio Measurement by In-Cell fs-LA-ICP-IDMS. Using the proposed in-cell fs-LA-ICP-IDMS method, two different aerosols (from the natural abundance sample and the isotopically enriched solid spike) were mixed in the ablation cell during incell fs-LA-ICP-IDMS analyses. However, no critical variations were observed for transient signals along LA-ICPMS profiles. Figure 3a illustrates the transient LA-ICPMS ion signals measured for soil CRM 142R using the in-cell isotope dilution method. Similar trends were observed for the different matrixes investigated (soil GBW-07405, and sediments PACS-2 and IAEA-405) although special attention was focused on the reference material CRM 142R as the matrix employed for the synthesis of the solid spike. Background signals were acquired during the first $20 \mathrm{~s}$. It can be seen that the ion signal intensities for the four elements investigated $(\mathrm{Cu}, \mathrm{Zn}, \mathrm{Sn}, \mathrm{Pb})$ presented several instabilities along the LA-ICPMS profile, which were significantly reduced by the isotope ratio measurement. Figure $3 \mathrm{~b}$ shows the values of the ${ }^{63} \mathrm{Cu} /{ }^{65} \mathrm{Cu}$, ${ }^{68} \mathrm{Zn} /{ }^{66} \mathrm{Zn},{ }^{118} \mathrm{Sn} /{ }^{119} \mathrm{Sn}$, and ${ }^{208} \mathrm{~Pb} /{ }^{207} \mathrm{~Pb}$ isotope ratios for each analysis time. The different trend observed for the time profile of the ${ }^{208} \mathrm{~Pb} /{ }^{207} \mathrm{~Pb}$ isotope ratio in comparison with the ${ }^{63} \mathrm{Cu} /{ }^{65} \mathrm{Cu}$, ${ }^{68} \mathrm{Zn} /{ }^{66} \mathrm{Zn}$, and ${ }^{118} \mathrm{Sn} /{ }^{119} \mathrm{Sn}$ isotope ratios can be explained, at least partly, by a different homogeneity of the elements in the samples. The local inhomogeneous distribution of the elements in the solid samples (for both the CRMs and the solid spike) as well as the incomplete aerosol mixing could affect the precision of the isotope ratio measurements and the accuracy of results, and therefore, a critical study of the in-cell laser ablation strategy was carried out.

In order to determine the isotope ratio precision during the ablation time for in-cell fs-LA-ICP-IDMS, the temporal relative standard deviations (TRSD) of ${ }^{63} \mathrm{Cu} /{ }^{65} \mathrm{Cu},{ }^{68} \mathrm{Zn} /{ }^{66} \mathrm{Zn},{ }^{118} \mathrm{Sn} /{ }^{119} \mathrm{Sn}$, and ${ }^{208} \mathrm{~Pb} /{ }^{207} \mathrm{~Pb}$ isotope ratios were calculated for soil CRM $142 \mathrm{R}$. The TRSD has been previously defined and used to describe LAICPMS transient signals. ${ }^{35}$ The TRSD of the isotope ratios is related to the short-term change and was calculated by dividing the standard deviation of the isotope ratio average by the isotope ratio-integrated value, for each analysis time. As can be seen in Table $2,{ }^{63} \mathrm{Cu} /{ }^{65} \mathrm{Cu},{ }^{68} \mathrm{Zn} /{ }^{66} \mathrm{Zn},{ }^{118} \mathrm{Sn} /{ }^{119} \mathrm{Sn}$, and ${ }^{208} \mathrm{~Pb} /{ }^{207} \mathrm{~Pb}$ isotope ratio measurements by in-cell fs-LA-ICP-IDMS showed

(35) Gonzalez, J.; Fernandez, A.; Mao, X. L.; Russo, R. E. Spectrochim. Acta, Part B 2004, 590, 369-374. 


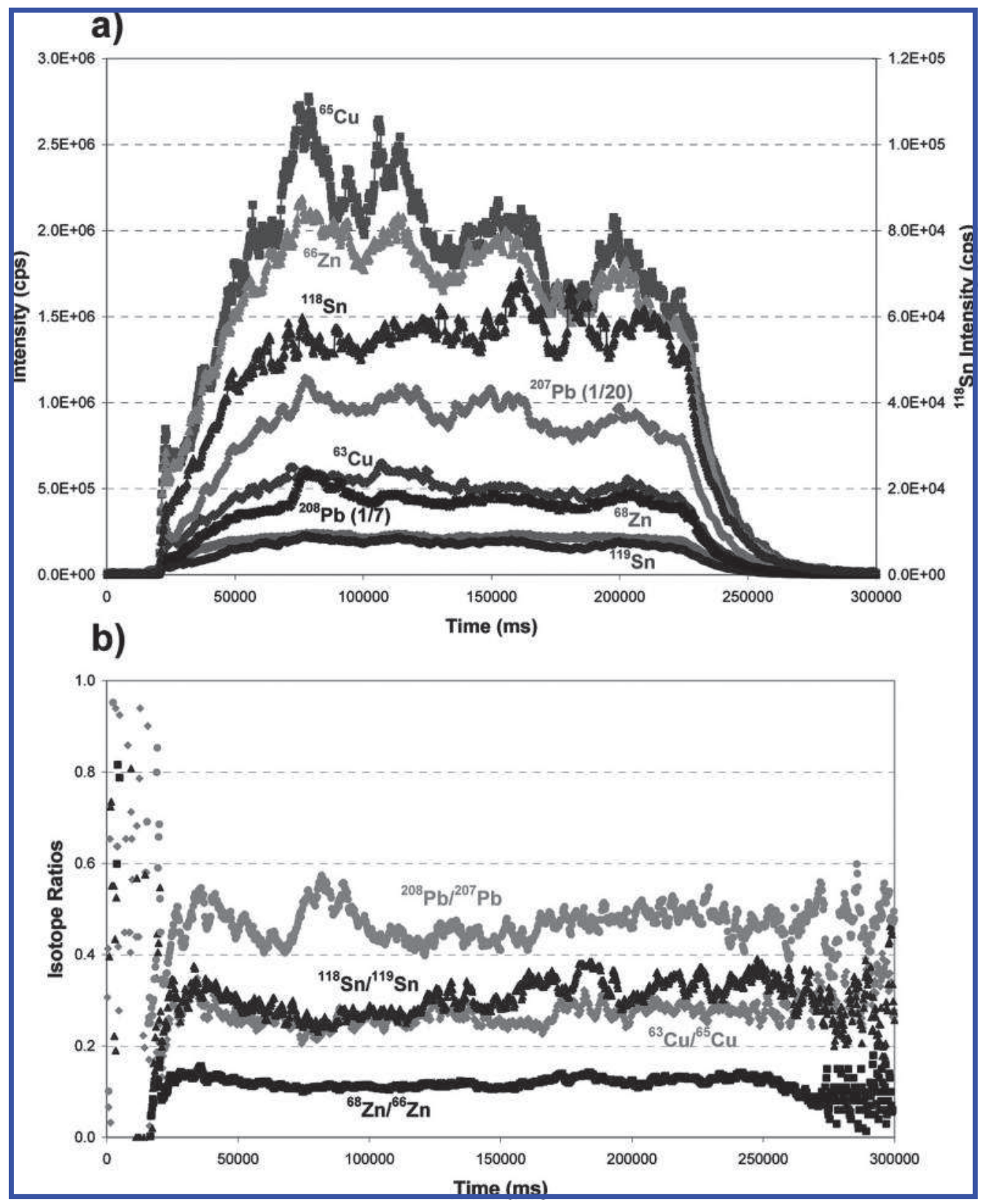

Figure 3. In-cell fs-LA-ICP-IDMS analysis of soil CRM 142R. Selected experimental conditions: ablated surface $300 \mu \mathrm{m} \times 1 \mathrm{~mm}$; sample translation speed $5 \mu \mathrm{m} \mathrm{s}^{-1}$; scanner speed (laser on) $200 \mathrm{~mm} \mathrm{~s}^{-1}$; scanner speed (laser off) $100 \mathrm{~mm} \mathrm{~s}^{-1}$; He flow rate $570 \mathrm{~mL} \mathrm{~min}^{-1}$. (a) Transient ion signals. (b) Isotope ratios.

precisions in the range of $6-10 \%$. Furthermore, the $2 \mathrm{D}$ scanning mode and the 2D elliptical strategy using a single pellet and using the same matrix for the two pellets were also studied in order to investigate the effect of the $2 \mathrm{D}$ elliptical ablation strategy and the aerosol mixing process on the precision of the isotope ratio measurements. For the 2D elliptical fs-LA analysis with the same matrix, two pellets of CRM 142R or two pellets of the solid spike were analyzed to study the influence of the sample matrix on the aerosol mixing process. For the 2D scanning ablation mode and the $2 \mathrm{D}$ elliptical fs-LA analysis with one pellet, the influence of the laser ablation strategy was investigated independently of the aerosol mixing process. Table 2 shows that for both matrixes (soil CRM 142R and the isotopically enriched solid spike) better precisions in the range of $4-6$ and $4-8 \%$ were obtained for the 2D elliptical fs-LA analysis with the same matrix and with one pellet, respectively, in comparison with those obtained by in-cell fs-LA-ICP-IDMS. Nevertheless, it can be stated that using in-cell fs-LA-ICP-IDMS precisions better than 10\% were achieved for all isotope ratios investigated, this values being similar to precisions obtained by the $2 \mathrm{D}$ scanning ablation mode in which a unique aerosol and a simple ablation strategy were employed. Concerning the ${ }^{118} \mathrm{Sn} /{ }^{119} \mathrm{Sn}$ isotope ratio measurement, the low concentration of $\mathrm{Sn}$ in the natural abundance sample and the solid spike $(4 \mu \mathrm{g}$ $\mathrm{g}^{-1}$ and $9 \mu \mathrm{g} \mathrm{g}^{-1}$, respectively) in comparison with $\mathrm{Cu}, \mathrm{Zn}$, and $\mathrm{Pb}$ concentrations (in the range of 40-101 and 304-399 $\mu \mathrm{g} \mathrm{g}^{-1}$, respectively) could explain, at least partly, the inferior precision obtained for the isotope ratio due to low ions statistics.

Optimization of Experimental Parameters. It was proved that the direct and simultaneous measurement of ${ }^{63} \mathrm{Cu} /{ }^{65} \mathrm{Cu},{ }^{68} \mathrm{Zn} /$ ${ }^{66} \mathrm{Zn}$, ${ }^{118} \mathrm{Sn} /{ }^{119} \mathrm{Sn}$, and ${ }^{208} \mathrm{~Pb} /{ }^{207} \mathrm{~Pb}$ isotope ratios by in-cell fs-LA-ICP- 
Table 2. Temporal Relative Standard Deviation of the ${ }^{63} \mathrm{Cu} /{ }^{65} \mathrm{Cu},{ }^{68} \mathrm{Zn} /{ }^{66} \mathrm{Zn},{ }^{118} \mathrm{Sn} /{ }^{119} \mathrm{Sn}$, and ${ }^{208} \mathrm{~Pb} /{ }^{206} \mathrm{~Pb}$ Isotope Ratios Produced by the Sampling Strategies 2D Elliptical (Ablated Surface $300 \mu \mathrm{m} \times 1 \mathrm{~mm}$; Scanner Speed $200 \mathrm{~mm}$ $\mathrm{s}^{-1}$; Sample Translation Speed $5 \mu \mathrm{m} \mathrm{s}^{-1}$ ) and 2D scan (Ablated Surface $100 \mu \mathrm{m} \times 1 \mathrm{~mm}$; Scanner Speed $2.0 \mathrm{~mm} \mathrm{~s}{ }^{-1}$; Sample Translation Speed $\left.10 \mu \mathrm{m} \mathrm{s}^{-1}\right)^{a}$

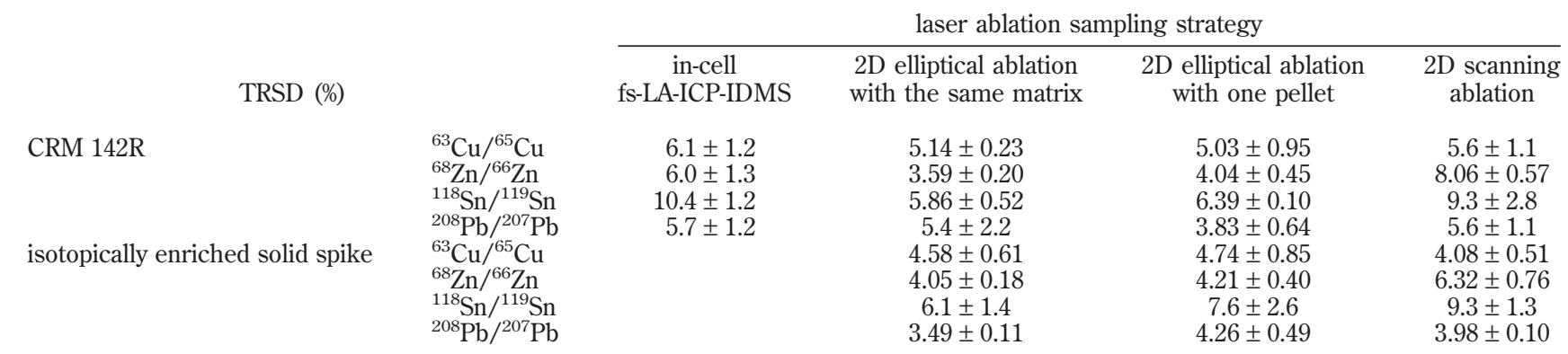

${ }^{a}$ Standard deviation values are calculated from the mean of three analyses using independent pellets.

IDMS can be carried out in soil and sediment samples with a precision lower than $10 \%$, given as temporal relative standard deviation. Nevertheless, using the proposed in-cell isotope dilution method, an additional and important consideration has to be taken into account. The isotopic mixing is a fundamental requirement to ensure not only the precision but also the accuracy of the analytical results, and therefore, a critical optimization of the experimental parameters was required to obtain a complete homogenization between the natural abundance sample and the solid spike aerosols. Before the analysis, the preablation of the natural abundance sample and the isotopically enriched solid spike was carried out to eliminate possible surface contamination,which can otherwise lead to wrong results, especially when samples with low concentrations are analyzed. Nevertheless, no significant differences were observed between in-cell fs-LA-ICPIDMS analyses with and without the preablation stage,and therefore, in-cell isotope dilution analysis was performed without the preablation of the pellets for all the subsequent measurement. Furthermore, it could be stated that the possibility of sample/ standard cross-contamination during the analysis can be considered negligible for the proposed in-cell isotope dilution methodology.

For the optimization studies, ${ }^{63} \mathrm{Cu} /{ }^{65} \mathrm{Cu},{ }^{68} \mathrm{Zn} /{ }^{66} \mathrm{Zn},{ }^{118} \mathrm{Sn} /$ ${ }^{119} \mathrm{Sn}$, and ${ }^{208} \mathrm{~Pb} /{ }^{207} \mathrm{~Pb}$ isotope ratio measurements were carried out in eight successive replicates per pellet. The precision of the measurements was calculated based on 1S-standard deviation from the eight independent replicates. The corresponding isotope ratios were corrected for detector dead time and for mass bias by the online nebulization of natural abundance standards. This means that the mass bias factor was performed in the same LA-ICPMS profile by using natural $\mathrm{Ga}$, $\mathrm{Sb}$, and $\mathrm{Tl}$ standards (Ga for $\mathrm{Cu}$ and $\mathrm{Zn}, \mathrm{Sb}$ for $\mathrm{Sn}$, and $\mathrm{Tl}$ for $\mathrm{Pb}$ ) with well-known isotopic composition. The calculation of in-cell fs-LA-ICP-IDMS results for the determination of $\mathrm{Cu}, \mathrm{Zn}$, Sn, and $\mathrm{Pb}$ was carried out by using the conventional applied IDMS equation. ${ }^{26,29}$ The mass taken from the natural abundance sample and the isotopically enriched solid spike was calculated by weighing both pellets before and after the analysis. In all cases, the mass measured for the pellets with the analytical balance was in the range of $0.021-0.024 \mathrm{~g}$, and the typical weighing of the solid materials using the proposed methodology was in the range of $0.7-1.3 \mathrm{mg}$, with a typical precision of $5 \%$ RSD for both the natural abundance and the enriched pellets.
Integration Interval. First, the variation of elemental concentrations along the LA-ICPMS profile was investigated in order to select the optimum integration window. Signal processing was performed using Excel spreadsheet software in all cases. Six time slices of $35 \mathrm{~s}$ were defined along the LA-ICPMS profile after signal stabilization, and the mean value for the ${ }^{63} \mathrm{Cu} /{ }^{65} \mathrm{Cu},{ }^{68} \mathrm{Zn} /{ }^{66} \mathrm{Zn}$, ${ }^{118} \mathrm{Sn} /{ }^{119} \mathrm{Sn}$, and ${ }^{208} \mathrm{~Pb} /{ }^{207} \mathrm{~Pb}$ isotope ratios recorded within each interval was used to calculate the corresponding concentrations. As an example, Figure 4 shows the variation of $\mathrm{Cu}, \mathrm{Zn}, \mathrm{Sn}$, and $\mathrm{Pb}$ concentrations along the profile obtained by in-cell fs-LA-ICPIDMS analysis of soil GBW-07405. Although moderate variations were observed in $\mathrm{Cu}, \mathrm{Zn}, \mathrm{Sn}$, and $\mathrm{Pb}$ concentrations along the LA-ICPMS profile, except for $\mathrm{Zn}$ in the first interval, the elemental concentrations were well in agreement with the certified values within the given uncertainties in all cases. It is worth noting that the behavior of $\mathrm{Zn}$ in the first integration interval in all individual measurements was not different in terms of deviation from the certified values. Nevertheless, the first interval (25-60 s) was discarded from the integration window due to the significantly higher uncertainty obtained in the concentration values for all the elements investigated in comparison with the rest of the integration intervals. In the first interval, the precisions of $\mathrm{Cu}, \mathrm{Zn}, \mathrm{Sn}$, and $\mathrm{Pb}$ concentrations were found to be over $20 \%(n=8)$, given as relative standard deviation, whereas precisions in the range of $7-15 \%$ were obtained for the other intervals. Therefore, according to the experimental results, it can be stated that using the proposed in-cell fs-LA-ICP-IDMS method an initial stabilization time is required to ensure the complete mixing between the sample and the solid spike aerosols. The optimum integration window was selected from 60 to $235 \mathrm{~s}$ for all the subsequent measurements.

In-Cell Flow Conditions. The precision and the deviation of the average concentration values of all the replicates from the certified values obtained by in-cell fs-LA-ICP-IDMS analysis can be affected by numerous experimental parameters such as the carrier gas flow rate, inlet diameter of the ablation cell, dimensions of the ablated surface, sample translation speed, and scanner speed (both when the laser beam is switched on and switched off). In order to ensure the isotopic mixing, different studies were performed using soil and sediment matrixes until reaching the optimum experimental conditions. Although all parameters were carefully investigated, special attention was focused on the 


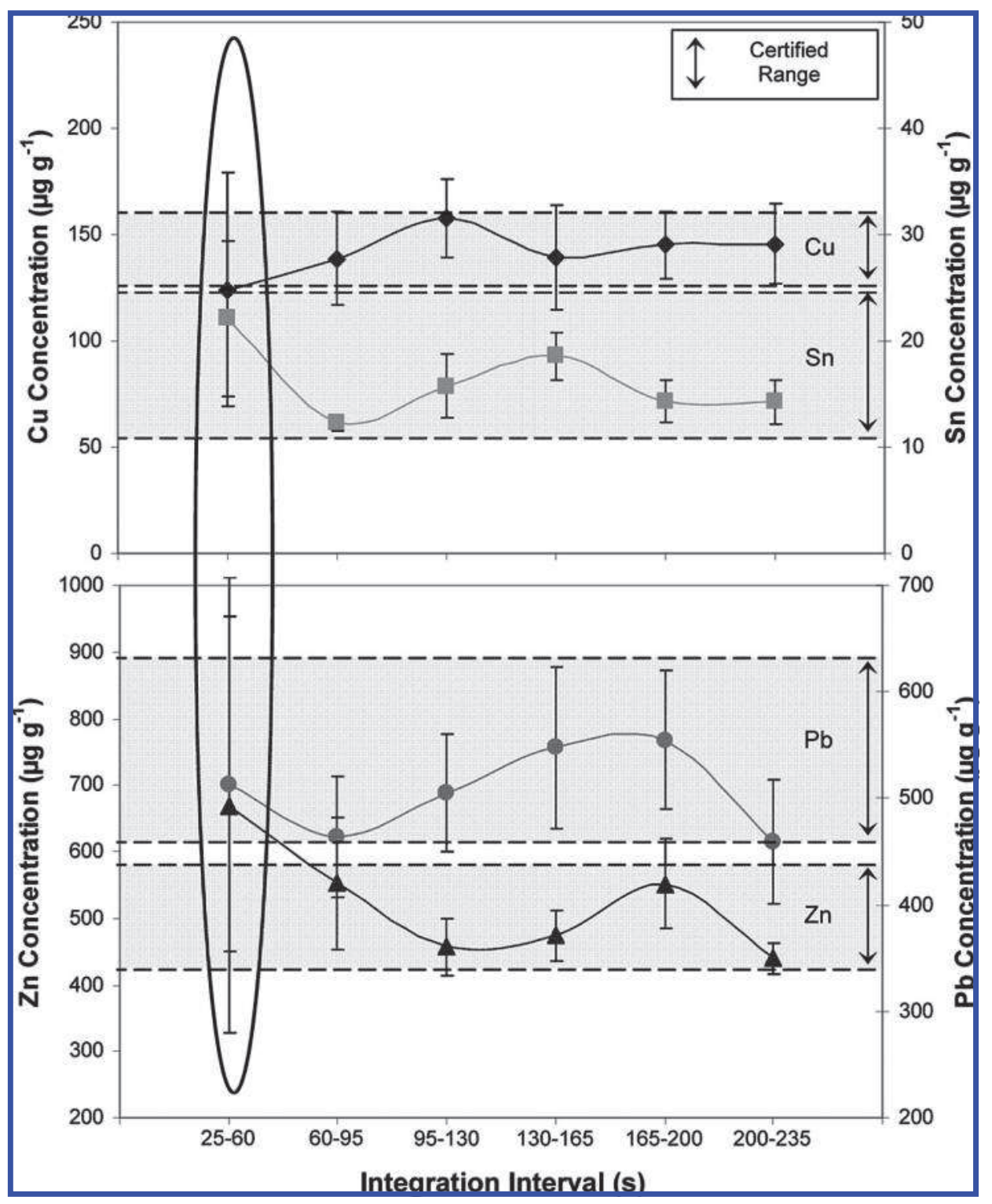

Figure 4. Variation of $\mathrm{Cu}, \mathrm{Zn}, \mathrm{Sn}$, and $\mathrm{Pb}$ concentrations along the LA-ICPMS profile obtained by in-cell fs-LA-ICP-IDMS analysis of soil GBW-07405. Selected experimental conditions: ablated surface $300 \mu \mathrm{m} \times 1 \mathrm{~mm}$; sample translation speed $5 \mu \mathrm{m} \mathrm{s}^{-1}$; scanner speed (laser on) $200 \mathrm{~mm} \mathrm{~s}^{-1}$; scanner speed (laser off) $100 \mathrm{~mm} \mathrm{~s}^{-1}$; He flow rate $570 \mathrm{~mL} \mathrm{~min}^{-1}$.

He flow rate, the diameter of the nozzle at the inlet of the ablation cell, and the speed of the scanner.

First, the elemental concentrations of $\mathrm{Cu}, \mathrm{Zn}, \mathrm{Sn}$, and $\mathrm{Pb}$ were investigated for soil GBW-07405 and sediment PACS-2 by fs-LAICP-IDMS at different flow conditions, equipping the cell with nozzles of 0.50 and $0.25 \mathrm{~mm}$ and using carrier gas flow rates in the range of $570-870 \mathrm{~mL} \mathrm{m^{-1 }}$. Similar results were achieved for the two matrixes, and Figure 5 shows the elemental concentrations obtained for sediment PACS-2. The sensitivities obtained for the in-cell fs-LA-ICP-IDMS analysis of reference material PACS-2 were in the range of $2 \times 10^{-5} \times 10^{6}$ counts/s for the three different inlet diameters and $\mathrm{He}$ flow rates investigated (in the order of 1 $\times 10^{6}$ counts/s for ${ }^{63} \mathrm{Cu}, 4 \times 10^{5}$ counts/s for ${ }^{68} \mathrm{Zn}, 2 \times 10^{5}$ counts $/ \mathrm{s}$ for ${ }^{118} \mathrm{Sn}$, and $5 \times 10^{6}$ counts/s for ${ }^{208} \mathrm{~Pb}$ ). The experiments were carried out under turbulent in-cell flow conditions for the three inlet diameters and He flow rates investigated. In comparison to laminar in-cell flow, turbulent conditions result in an almost complete aerosol homogenization ${ }^{15,36}$ and, therefore, should be used if the average signals of an inhomogeneous sample have to be averaged by long mixing times in the cell or, as in our case, if a homogeneous aerosol has to be obtained from two individual aerosols. In addition, according to recent experimental results reported by Koch et al., ${ }^{37}$ the utilization of turbulent in-cell flow results in an almost complete aerosol homogenization in the ablation cell, whereas using laminar in-cell flow regions of lower particle density and, most probably, higher gas velocity can be found.

As can be seen in Figure 5, Cu, $\mathrm{Zn}, \mathrm{Sn}$, and $\mathrm{Pb}$ concentrations as well as their corresponding relative standard deviations increased for the three inlet diameters investigated when the He flow rate went up, especially for $870 \mathrm{~mL} \mathrm{~min}^{-1}$. Although the

(36) García, C. C.; Ẅ; alle, M.; Lindner, H.; Koch, J.; Niemax, K.; Günther, D. Spectrochim. Acta, Part B 2008, 63, 271-276.

(37) Koch, J.; Wälle, M.; Dietiker, R.; Günther, D. Anal. Chem. 2008, 80, 915921. 


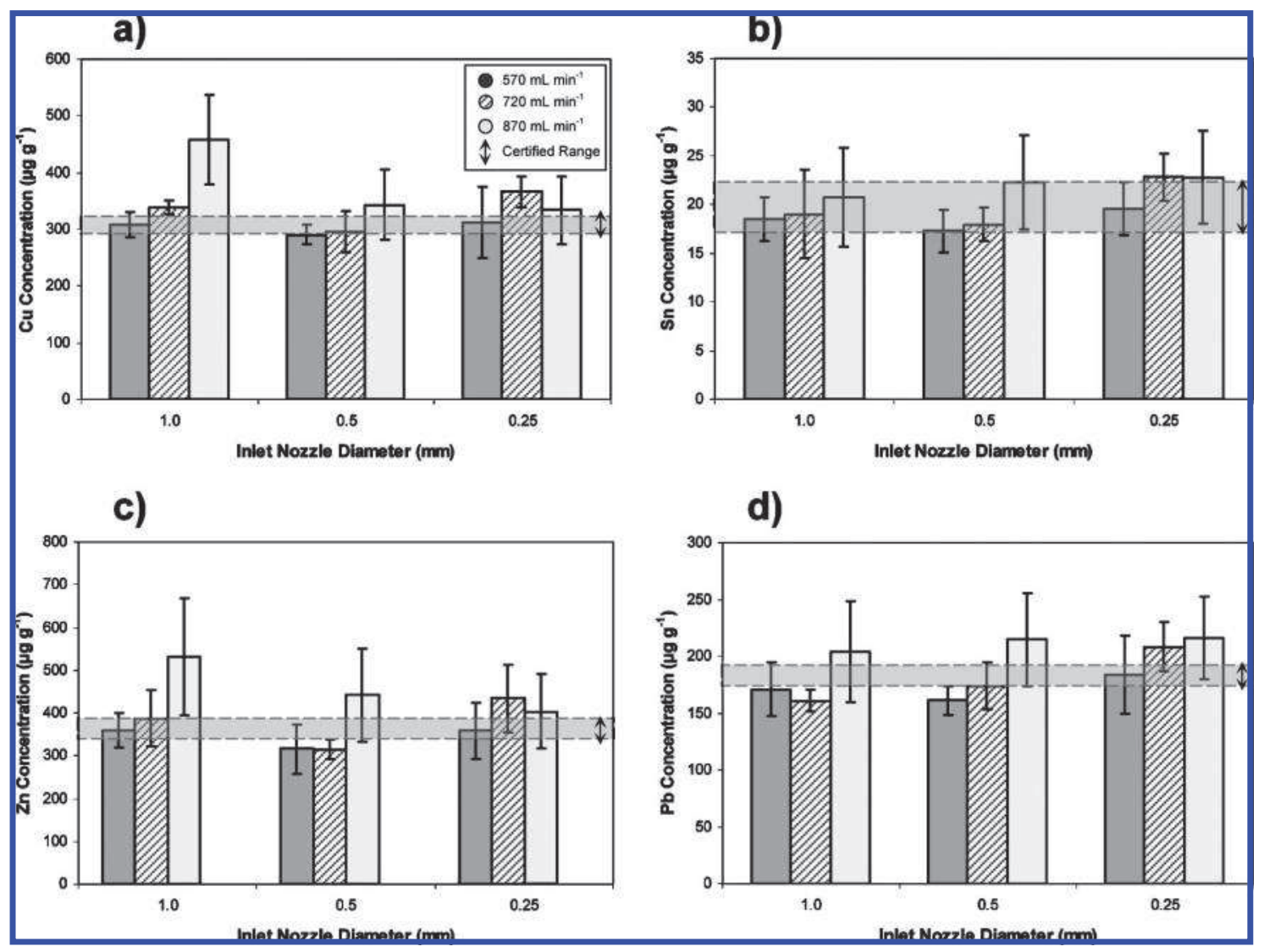

Figure 5. Influence of the He flow rate and the nozzle diameter at the inlet of the ablation cell on the elemental concentrations of sediment PACS-2 obtained by in-cell fs-LA-ICP-IDMS. Selected experimental conditions: ablated surface $300 \mu \mathrm{m} \times 1 \mathrm{~mm}$; sample translation speed 5 $\mu \mathrm{m} \mathrm{s}^{-1}$; scanner speed (laser on) $200 \mathrm{~mm} \mathrm{~s}^{-1}$; scanner speed (laser off) $100 \mathrm{~mm} \mathrm{~s}^{-1}$. Standard deviation values are calculated from the mean of eight analyses using three independent pellets for both the CRM and the solid spike. (a) Copper. (b) Tin. (c) Zinc. (d) Lead.

elemental concentrations obtained were in agreement with the certified values for several in-cell flow conditions, the precision of trace elemental concentrations was always better for the 1.0and 0.5 -mm inlet diameter. However, since a better isotope ratio stability along the LA-ICPMS profile was obtained for the 1.0-mm inlet, the original inlet of the ablation cell was selected for all the subsequent measurements. Using the 1.0-mm inlet diameter and a He flow rate of $570 \mathrm{~mL} \mathrm{~min}^{-1}, \mathrm{Cu}, \mathrm{Zn}, \mathrm{Sn}$, and $\mathrm{Pb}$ concentrations showed precisions better than $14 \%$ and the deviation of the average concentration values of all the replicates from the certified values was in the range of $1-7 \%$.

Scanner Speed. On the other hand, it can be highlighted that one of the most critical parameters for the in-cell sampling strategy is the scanner speed when the laser beam is switched off. The scanner speed when the laser is switched on and the sample translation speed are related to the overlapping of the small craters (corresponding to the laser beam spot size) in the ablated surface. However, the scanner speed when the laser beam is switched off is directly related not only to the craters overlapping but also to the analysis time (i.e., the time necessary for one elliptical movement between the two pellets) and, therefore, to the mixing process between the sample and the solid spike aerosols. The higher the scanner speed when the laser is switched off, the shorter the time necessary to cover the distance between the two pellets and, thus, the higher the overlap between the craters of two consecutives semicircles. Figure 6 shows the elemental concentrations obtained by fs-LA-ICP-IDMS for soil GBW-07405 and sediment PACS-2 using four different scanner speeds in the range of $50-500 \mathrm{~mm} \mathrm{~s}^{-1}$ (analysis time in the range of 15-150 $\mathrm{ms}$, respectively). Due to the complex trajectory described for the laser beam using the in-cell sampling strategy, the ablation yield is not exactly the same at the two analysis positions (at the natural abundance sample and the solid spike pellets), which make more difficult the mixing of the two aerosols in an optimum analyte/spike ratio. Furthermore, at high scanner speeds, the higher density of the aerosol and the accumulation of ejected particles in front of the samples' surface could decrease the coupling efficiency due to absorption/diffusion of the incident laser beam by the accumulated particles. ${ }^{38,39}$ The higher the scanner speed, the greater the overlap of the small craters (corresponding to the laser beam spot size) in the ablated surface and, also, the greater the probability of particles accumulation in front of the sample surface. The value of $100 \mathrm{~mm} \mathrm{~s}^{-1}$ was selected as the optimum scanner speed to achieve complete aerosol homogenization since much improved precision of $\mathrm{Cu}, \mathrm{Zn}, \mathrm{Sn}$, and $\mathrm{Pb}$ concentrations as well as deviation of the average concentration values of all the replicates from the certified values were obtained for both matrixes in comparison with higher scanner speeds.

(38) Gonzalez, J. J.; Fernandez, A.; Oropeza, D.; Mao, X.; Russo, R. E. Spectrochim. Acta, Part B 2008, 63, 277-286.

(39) Brygo, F.; Dutouquet, Ch.; Le Guern, F.; Oltra, R.; Semerok, A.; Weulersse, J. M. Appl. Surf. Sci. 2006, 252, 2131-2138. 

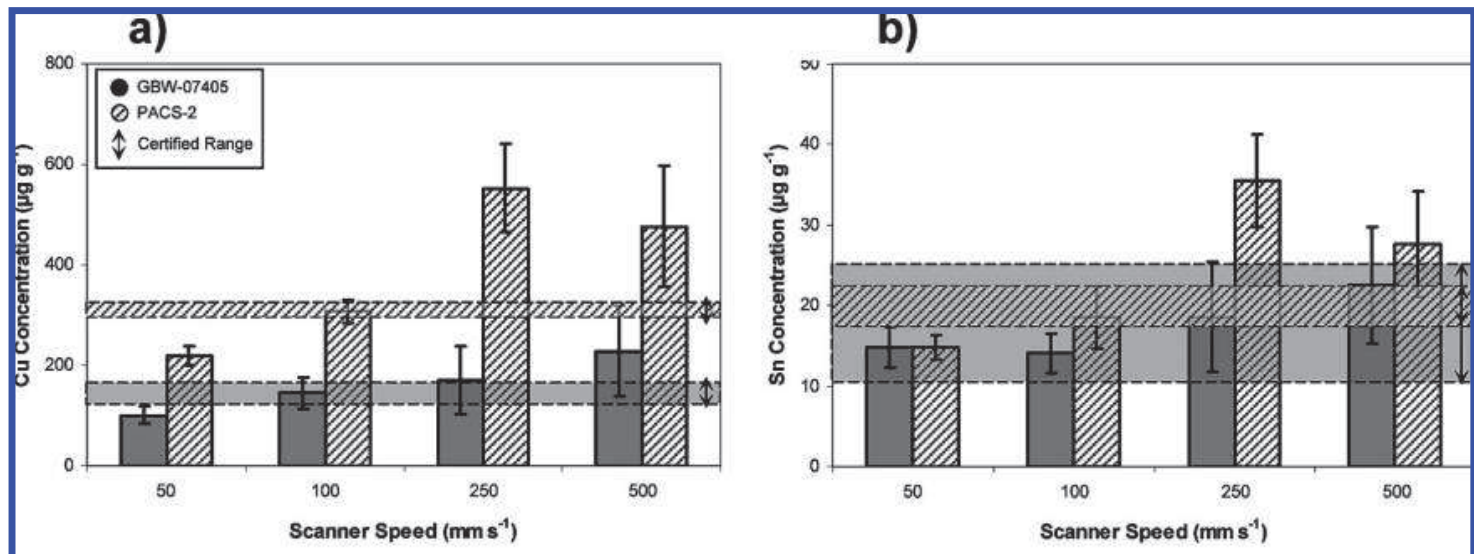

c)
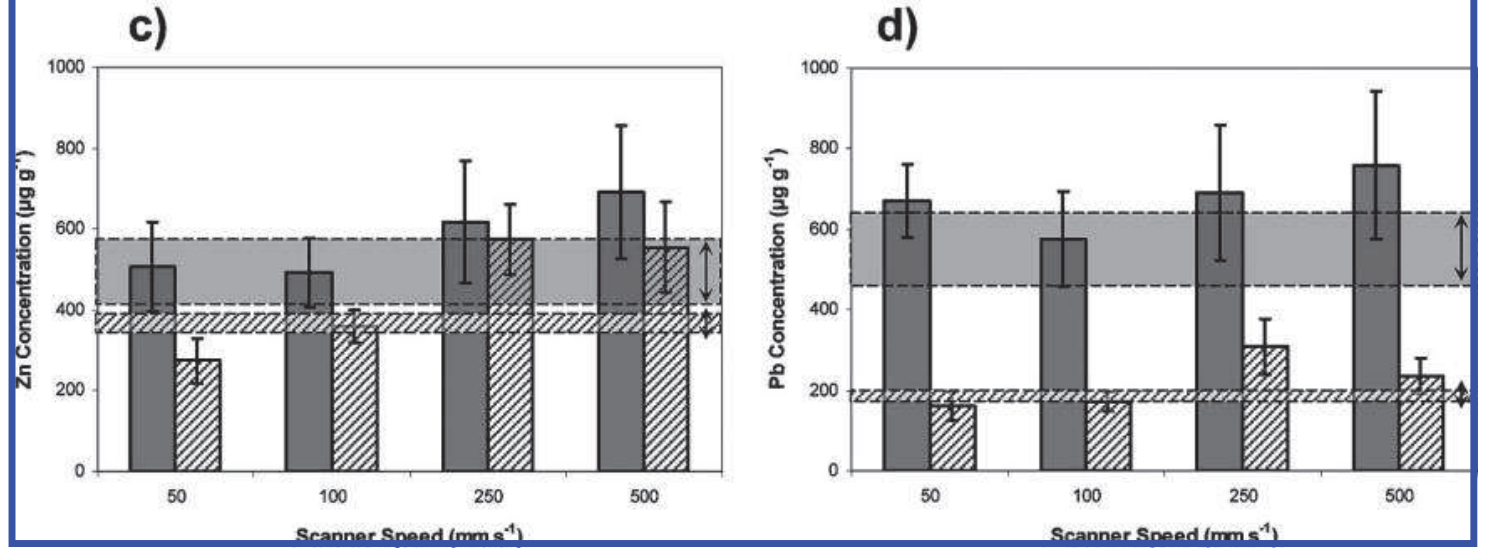

Figure 6. Influence of the scanner speed (when the laser beam is switched off) on the elemental concentrations of soil GBW-07405 and sediment PACS-2 obtained by in-cell fs-LA-ICP-IDMS. Selected experimental conditions: ablated surface $300 \mu \mathrm{m} \times 1 \mathrm{~mm}$; sample translation speed $5 \mu \mathrm{m} \mathrm{s}^{-1}$; scanner speed (laser on) $200 \mathrm{~mm} \mathrm{~s}^{-1}$; He flow rate $570 \mathrm{~mL} \mathrm{~min}^{-1}$; inlet diameter $1.0 \mathrm{~mm}$. Standard deviation values are calculated from the mean of eight analyses using three independent pellets for both the CRMs and the solid spike. (a) Copper. (b) Tin. (c) Zinc. (d) Lead.

In-Cell fs-LA-ICP-IDMS Analysis of Soil and Sediment Reference Materials. The main advantage of the quantification method proposed in this work relies on the possibility of carrying out a high number of analyses in a very short period of time using a simple sample preparation procedure. Once the isotopically enriched solid spike has been synthesized, the unique preparation process required for fs-LA-ICP-IDMS analysis is the preparation of pellets for each sample of interest in a laboratory press, which reduces the sample preparation time to less than $5 \mathrm{~min}$. The results for the determination of $\mathrm{Cu}, \mathrm{Zn}, \mathrm{Sn}$, and $\mathrm{Pb}$ in four certified reference materials by in-cell fs-LA-ICP-IDMS are summarized in Table 3. In addition, the table shows for comparison the certified values of the different materials as well as the values obtained by ICP-IDMS after the microwave-assisted digestion of the samples and by solid-spiking fs-LA-ICP-IDMS. ${ }^{28}$ For each reference material, ${ }^{63} \mathrm{Cu} /{ }^{65} \mathrm{Cu},{ }^{68} \mathrm{Zn} /{ }^{66} \mathrm{Zn},{ }^{118} \mathrm{Sn} /{ }^{119} \mathrm{Sn}$, and ${ }^{208} \mathrm{~Pb} /{ }^{207} \mathrm{~Pb}$ isotope ratio measurements were carried out in 39 replicates using 3 independent pellets for both the isotopically enriched solid spike and the natural abundance samples. Precisions better than $4 \%$, given as relative standard deviation, between the three independent pellets were achieved for all isotope ratios investigated, and therefore, it can be stressed that no significant differences were found between the different sample specimens.

As can be seen in Table 3 , the concentrations determined by in-cell fs-LA-ICP-IDMS were well in agreement with the corresponding certified or indicative values within the given uncertainties in all cases. The precision of $\mathrm{Cu}, \mathrm{Zn}, \mathrm{Sn}$, and $\mathrm{Pb}$ determinations was always better than $15 \%$ and the deviation of the average concentration values of all the replicates from the certified values obtained was better than $10 \%$, in some cases being as good as 0.3 ( $\mathrm{Cu}$ in CRM 142R) or 3\% ( $\mathrm{Zn}$ in IAEA-405 and $\mathrm{Pb}$ in CRM 142R). Only for the determination of $\mathrm{Zn}$ and $\mathrm{Pb}$ in the reference material GBW-07405 and for $\mathrm{Zn}$ in CRM $142 \mathrm{R}$ was a deviation higher than $10 \%$ observed. It should be stressed that, due mainly to the mixing process between the two aerosols, the precision obtained by in-cell fs-LA-ICP-IDMS was in most cases slightly higher than the precision obtained by solid-spiking fs-LA-ICP-IDMS (below 10\%). However, the total analysis time was significantly reduced since the synthesis process of isotope-diluted blend samples, which also introduced an extra inhomogenization step in the sample preparation procedure, was eliminated from the analytical protocol. Furthermore, compared to previous calibration strategies based on the direct addition of liquid spike solutions to the powdered samples, in-cell fs-LA-ICP-IDMS allows simplification of the sample preparation procedure and improvement of the precision. Boulyga et al. ${ }^{40}$ reported accuracies in the range of $4-17 \%$ and precisions over $15 \%$ (in the range of $7-20 \%$ for $\mathrm{Cu}$ and $7-22 \%$ for $\mathrm{Pb}$ ) for the direct determination of trace elements in sediment samples. Moreover, the precision and the deviation of the average concentration values of all the replicates from the certified values obtained by in-cell fs-LA-ICP-IDMS agree

(40) Boulyga, S. F.; Heumann, K. G. J. Anal. At. Spectrom. 2004, 19, 15011503. 
Table 3. Determination of Trace Element Concentrations (in $\mu \mathrm{g} \mathrm{g}^{-1}$ ) in Soil and Sediment Reference Materials by In-Cell fs-LA-ICP-IDMS Compared with the Certified Values and the Values Obtained by Solid-Spiking fs-LA-ICP-IDMS and the ICP-IDMS Wet Digestion Method ${ }^{a}$

\begin{tabular}{|c|c|c|c|c|}
\hline element/sample & $\begin{array}{c}\text { in-cell } \\
\text { fs-LA-ICP-IDMS }\end{array}$ & $\begin{array}{c}\text { solid-spiking } \\
\text { fs-LA-ICP-IDMS }\end{array}$ & $\begin{array}{l}\text { wet digestion } \\
\text { ICP-IDMS }^{26}\end{array}$ & $\begin{array}{l}\text { certified } \\
\text { value }\end{array}$ \\
\hline \multicolumn{5}{|l|}{ copper } \\
\hline GBW-07405 & $136.6 \pm 19.9$ & $159.6 \pm 13.4$ & $152.631 \pm 0.376$ & $144 \pm 19$ \\
\hline CRM 142R & $69.5 \pm 10.2$ & $69.26 \pm 4.06$ & $69.94 \pm 1.13$ & $69.7 \pm 1.3$ \\
\hline PACS-2 & $280.1 \pm 36.5$ & $324.0 \pm 14.5$ & $317.58 \pm 2.47$ & $310 \pm 12$ \\
\hline IAEA-405 & $46.65 \pm 5.99$ & $54.41 \pm 3.31$ & $49.330 \pm 0.211$ & $47.7 \pm 1.2$ \\
\hline \multicolumn{5}{|l|}{ zinc } \\
\hline GBW-07405 & $592.8 \pm 77.5$ & $483.8 \pm 44.9$ & $511.56 \pm 3.51$ & $494 \pm 79$ \\
\hline CRM 142R & $118.4 \pm 13.0$ & $119.8 \pm 12.6$ & $108.270 \pm 0.418$ & $(101)^{b}$ \\
\hline PACS-2 & $353.5 \pm 49.4$ & $349.6 \pm 28.0$ & $374.53 \pm 8.04$ & $364 \pm 23$ \\
\hline IAEA-405 & $271.2 \pm 25.3$ & $258.9 \pm 21.2$ & $283.51 \pm 2.39$ & $279 \pm 7$ \\
\hline \multicolumn{5}{|l|}{ tin } \\
\hline GBW-07405 & $15.98 \pm 2.38$ & $16.974 \pm 0.975$ & $14.8623 \pm 0.0881$ & $17.7 \pm 7.3$ \\
\hline CRM 142R & $3.012 \pm 0.322$ & $4.773 \pm 0.834$ & $4.1211 \pm 0.0348$ & \\
\hline PACS-2 & $19.21 \pm 2.80$ & $18.71 \pm 1.74$ & $17.638 \pm 0.870$ & $19.8 \pm 2.5$ \\
\hline IAEA-405 & $7.72 \pm 1.08$ & $9.963 \pm 0.791$ & $8.8498 \pm 0.0617$ & $7.6 \pm 1.3$ \\
\hline \multicolumn{5}{|l|}{ lead } \\
\hline GBW-07405 & $642.8 \pm 86.9$ & $560.8 \pm 29.4$ & $664.89 \pm 1.72$ & $552 \pm 88$ \\
\hline CRM 142R & $41.40 \pm 3.69$ & $38.10 \pm 1.62$ & $38.707 \pm 0.866$ & $40.2 \pm 1.9$ \\
\hline PACS-2 & $173.5 \pm 24.9$ & $171.00 \pm 7.40$ & $189.82 \pm 7.51$ & $183 \pm 8$ \\
\hline IAEA-405 & $80.11 \pm 6.35$ & $76.61 \pm 1.23$ & $82.928 \pm 0.529$ & $74.8 \pm 2.2$ \\
\hline
\end{tabular}

${ }^{a}$ Standard deviation values for in-cell fs-LA-ICP-IDMS analyses are calculated from the mean of thirty-nine measurements in three independent pellets for both the CRMs and the solid spike. ${ }^{b}$ Indicative noncertified value is also given for information.

well with an accurate, sensitive, and robust isotope dilution LAICPMS method recently presented. ${ }^{41} \mathrm{~A}$ high ablation rate laser system and a sector field ICPMS were used for the determination of trace elements in coal samples, and the relative standard deviations for $\mathrm{Cu}, \mathrm{Zn}$, and $\mathrm{Pb}$ were higher (in the range of $13-25 \%$ for $\mathrm{Cu}, 10-36 \%$ for $\mathrm{Zn}$, and $12-25 \%$ for $\mathrm{Pb}$ ) than precisions obtained by in-cell fs-LA-ICP-IDMS (always below 15\%).

In addition, the agreement of the in-cell fs-LA-ICP-IDMS data with the values obtained by conventional ICP-IDMS after the microwave-assisted digestion method demonstrates the high accuracy of the proposed quantification method for the determination of trace elements in powdered samples. As expected, the precision observed for ICP-IDMS analyses was better than that obtained for LA-ICP-IDMS, reflecting the well-known high precision of the isotope dilution technique for wet chemical procedures. The contribution of sample preparation (analyte losses and contamination), the high influence of sample inhomogeneities, and the relatively small sample volume analyzed by the laser ablation may be three of the factors that affect the precision and accuracy of LA-ICP-IDMS analyses. However, Moser et al. ${ }^{42}$ demonstrated that the contribution of the sample heterogeneity to the combined IDMS uncertainty exceeds the contributions from most other uncertainty components. This effect is also increased by the low ablated sample amount used in the laser ablation technique, which explains the relatively high standard deviations observed by LA-ICPIDMS determinations in comparison to those obtained by ICPIDMS. Additionally, using the proposed in-cell fs-LA-ICP-IDMS method, a supplementary factor should be taken into account in the combined IDMS uncertainty. The incomplete homog-

(41) Boulyga, S. F.; Heilmann, J.; Phohaska, T.; Heumann, K. G. Anal. Bioanal. Chem. 2007, 389, 697-706.

(42) Moser, J.; Wegscheider, W.; Meisel, T.; Fellner, N. Anal. Bioanal. Chem. 2003, 377, 97-110. enization between the natural abundance sample and the solid spike aerosols would have a direct effect on the isotopic mixing and, therefore, on the accuracy and precision. Nevertheless, the appropriate selection of experimental parameters for the in-cell laser ablation strategy was found to allow the accurate, precise, and fast determination of trace elements in powdered soil and sediment samples.

Evaluation of Uncertainty Sources. In order to study the influence of the weighing step in the final uncertainty of the concentration values, we have calculated full uncertainty budgets for all the elements investigated in a representative analysis of each of the four different CRMs using the method proposed by Kragten. ${ }^{43}$ The results obtained for a representative analysis for each material are included as Supporting Information as Tables S1, S2, S3, and S4 for $\mathrm{Cu}, \mathrm{Zn}$, Sn, and $\mathrm{Pb}$, respectively. As can be observed from the tables, the uncertainty of the concentration values is in all cases dominated by the precision of the isotope ratio measurement of the mixed aerosol, being the influence of the weighing lower than $15 \%$ for both natural and enriched materials. According to these results, we can conclude that the main factor influencing the achievement of the isotopic mixing is the mixing process of both materials during the ablation process rather than the weighing of the pellets. Other factors that are important in more conventional ID-MS methodologies, such as the uncertainty in the concentration of the spike solution or the precision of the measurement of the isotope ratios for the mass bias correction, are negligible in the proposed approach. This is explained by the fact that our spike solution has been characterized in terms of isotope abundances and concentrations using ICP-IDMS wet digestion methods and that the correction of the mass bias has been performed from the online measurement of a natural abundance standard nebulized during the analysis.

(43) Kragten, J. Analyst 1994, 119, 2161-2165. 


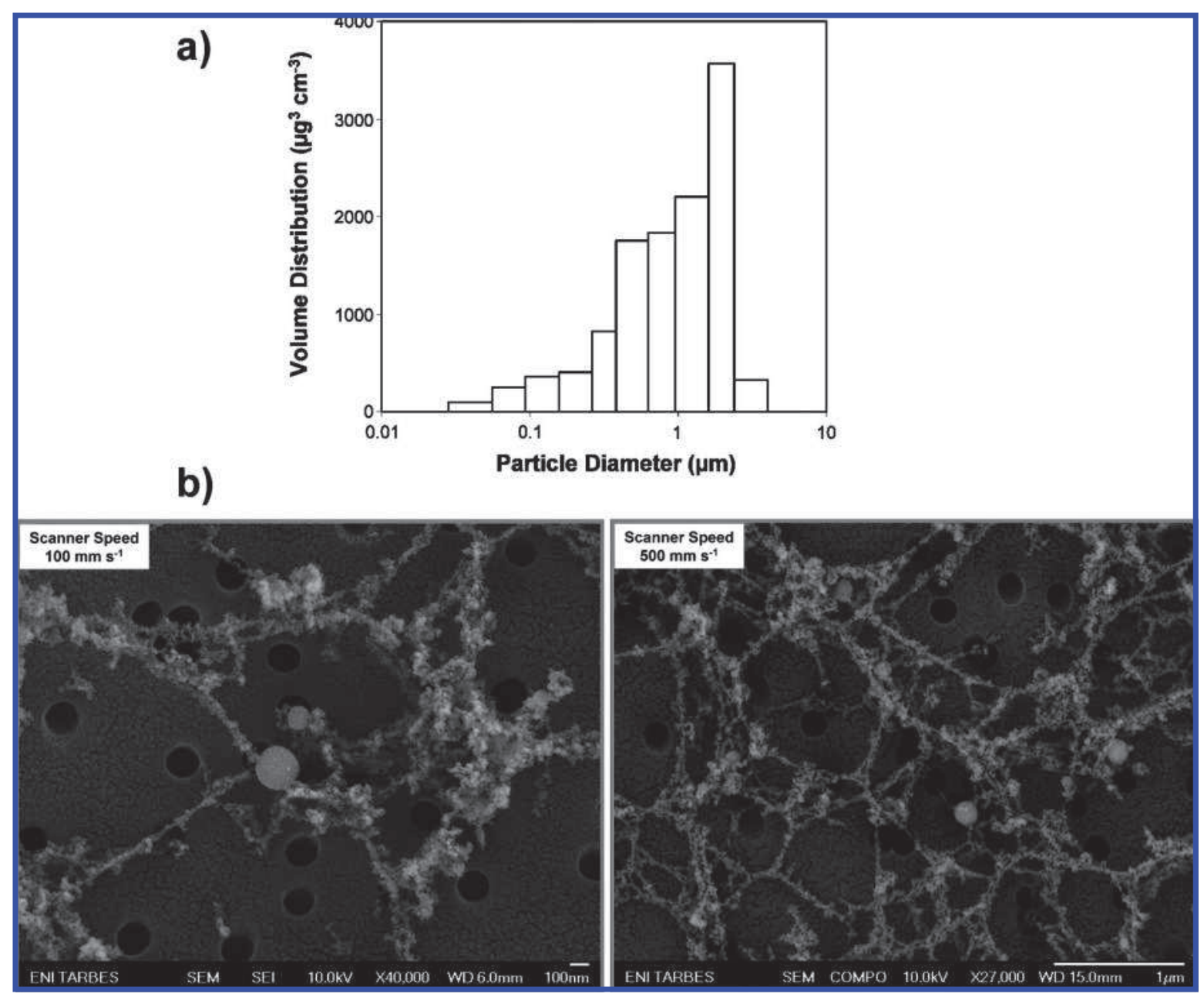

Figure 7. Particle size distribution and structure of the laser-generated aerosol after in-cell fs-LA-ICP-IDMS analysis of sediment PACS-2. (a) Particle size distribution of the generated aerosol measured by ELPI. (b) SEM images of the collected aerosol particles using two scanner speeds (100 and $500 \mathrm{~mm} \mathrm{~s}^{-1}$, respectively). These images show the different kinds of transported particles observed for each scanner speed but are not representative of the total transported mass.

Particle Size Distribution and Physical Characteristics of the Transported Aerosol. Knowledge about aerosol particle sizes in laser-generated aerosols and fundamental understanding of aerosol formation and particle transport are important aspects to better understand and improve LA-ICPMS analysis. As has been widely reported, laser-generated aerosols consist of spherical particles as well as agglomerated nanoparticles. ${ }^{44,45}$ Furthermore, it has been proved that laser ablation on the femtosecond time scale produces smaller particles that form large agglomerates in comparison with large particles and small agglomerates from nanosecond ablation..$^{7,46,47}$ In this sense, Gonzalez et al. ${ }^{48,49}$ have been recently demonstrated that the particles produced from femtosecond laser ablation of glass and metal samples consisted of "soft" agglomerates formed

(44) Khun, H.-R.; Koch, J.; Hergenröder, R.; Niemax, K.; Kalberer, M.; Günther, D. J. Anal. At. Spectrom. 2005, 20, 894-900.

(45) Khun, H.-R.; Günther, D. Anal. Bioanal. Chem. 2005, 383, 434-441.

(46) Saetveit, N. J.; Bajic, S. J.; Baldwin, D. P.; Houk, R. S. J. Anal. At. Spectrom. 2007, 23, 54-61.

(47) Mozná, V.; Pisonero, J.; Holá, M.; Kanicky, V.; Günther, D. J. Anal. At. Spectrom. 2006, 21, 1194-1201.

(48) Gonzalez, J. J.; Liu, C.; Wen, S.-B.; Mao, X.; Russo, R. E. Talanta 2007. $73,567-576$.

(49) Gonzalez, J. J.; Liu, C.; Wen, S.-B.; Mao, X.; Russo, R. E. Talanta 2007, $73,577-582$. from numerous small particles as well as of spherical primary particles in the nanometers range. In order to evaluate the influence of the quasi-simultaneous ablation of the natural abundance sample and the isotopically enriched solid spike on the particles entering the ICP, the particle size and structure of the laser-generated aerosol were investigated by using the proposed in-cell fs-LA-ICP-IDMS method. The particle size distribution (PSD) was determined by low-pressure impaction, and the size and shape of the particles were directly accessible using SEM.

The particle size distribution of the generated aerosol after in-cell fs-LA-ICP-IDMS analysis of sediment PACS-2 was measured using the experimental conditions selected to achieve complete aerosol homogenization. Based on electrical lowpressure impaction (ELPI) experiments, the volume distribution $\left(\mu \mathrm{m}^{3} / \mathrm{cm}^{3}\right)$ was calculated and related to the particle diameter $(\mu \mathrm{m})$. Figure $7 \mathrm{a}$ shows the PSD of the aerosol measured, and as can be seen, a monomodal aerosol was generated under incell laser ablation strategy. Since it has been widely proved that femtosecond laser ablation produces small particles that form large agglomerates, ${ }^{46-49}$ in this case, it could be stated that the aerosol predominantly consisted of agglomerates in the range of $500 \mathrm{~nm}$ up to $2.5 \mu \mathrm{m}$, with a maximum volume 
distribution at a particle size diameter of $2.5 \mu \mathrm{m}$. According to experimental results, it is probable that agglomerates were collected and classified to be significantly larger than their actual primary particle size, and therefore, the relative maximum of the PSD observed at $2.5 \mu \mathrm{m}$ did not directly mean that single large particles in the micrometer range were produced by in-cell fs-LA-ICP-IDMS.

In order to evaluate the size and morphology of the extracted aerosol particles as well as to demonstrate that the aerosol mainly consisted of large agglomerates of small particles, the generated aerosol was collected on filters and analyzed using a scanning electron microscope. The filters were placed in the transfer tube $\sim 1 \mathrm{~m}$ behind the ablation cell to collect the aerosol particles. Nuclepore polycarbonate tracketch membrane filters with a pore size of $200 \mathrm{~nm}$ were found to be suitable for the experiments (Whatman Inc.), and the filters were placed on SEM mounts using a conducting carbon tape enabling SEM measurements after deposition of a $\mathrm{Pd}$ conductive surface coating. Figure $7 \mathrm{~b}$ shows typical SEM images of the collected aerosol particles obtained for soil and sediment samples using in-cell fs-LA-ICP-IDMS. While the SEM images cannot be used to provide quantitative information about particle size distribution due to the nonuniform distribution of particles on filter surfaces, they reveal the shape and texture of the particles, which provides crucial information about particle formation processes. It was observed that, using incell fs-LA-ICP-IDMS, linear agglomerates and a few large molten spherical particles with diameters of $<225 \mathrm{~nm}$ were detected. Furthermore, although there is a higher density of the aerosol and a greater accumulation of ejected particles in front of the samples' surface at high scanner speeds, the structure of the agglomerates and the number of molten spherical particles were similar for low and high scanner speeds (100 and $500 \mathrm{~mm} \mathrm{~s}^{-1}$, respectively). SEM measurements proved that particles in the micrometer range were not produced by in-cell fs-LA-ICP-IDMS, and therefore, one possible explanation for the discrepancies observed between the impaction measurements and the SEM images is that the presence of agglomerates would affect the particle impaction technique used for particle-size determination since the large agglomerates were not classified according to the size of their primary particles, which were in the order of a few tens of nanometers. Further investigations should be carried out for more critical evaluation of the impaction technique used for particle-size distribution measurements and, thus, for clarifying the cause of the discrepancies observed between the SEM images and the impaction measurements. Finally, it might be stressed that these large agglomerates could be effectively homogenized and digested in the ICP since accurate and precise determinations were achieved.

\section{CONCLUSIONS}

In-cell fs-LA-ICP-IDMS is an accurate, precise, and timeeffective method that offers the possibility for direct and simultaneous determination of trace elements in powdered soil and sediment samples at concentration levels down to the low microgram per gram range. Compared with other quantification methodologies widely investigated, no calibration curves, standard reference materials, or tedious isotope dilution stages, such as the homogenizations of the isotope-enriched spike solutions with the solid samples, were necessary using the proposed method. The innovative laser ablation strategy designed for in-cell fs-LA-ICP-IDMS analysis allowed the quasisimultaneous ablation of the natural abundance sample and the multielement isotopically enriched solid spike, which reduced the sample preparation time to less than 5 min. Furthermore, the appropriate selection of experimental parameters $(570 \mathrm{~mL}$ $\min ^{-1} \mathrm{He}$ flow rate, $1.0 \mathrm{~mm}$ inlet diameter of the ablation cell, and $100 \mathrm{~mm} \mathrm{~s}^{-1}$ scanner speed laser off) was found to ensure a complete aerosol homogenization and, thus, a good precision and deviation of the average concentration values of all the replicates from the certified values for in-cell fs-LA-ICP-IDMS results. Although the methodology proposed in this work has never been claimed to be an absolute method of analysis and IDMS using LA-ICPMS is still at an early stage, under the precondition that a suitable solid spike is available and the isotopic mixing is achieved, in-cell fs-LA-ICP-IDMS opens the possibility in the future to become an accurate and fast method in industry for multielement trace determinations in different powdered samples.

The main disadvantage of LA-ICP-IDMS relies on its application to compact solids and to the determination of monoisotopic elements. In addition, local inhomogeneous distributions in the solid samples can affect the precision and accuracy of analyses, leading to high standard deviations of the mean for elements distributed heterogeneously. Even if the proposed in-cell isotope dilution method introduces a critical step with the mixing process between the natural sample and the solid spike aerosols and using laser ablation sampling the ablated sample amount is very low (in the ng range), the precision and the deviation of the average concentration values of all the replicates from the certified values obtained by incell fs-LA-ICP-IDMS were in agreement and even better than those obtained by previous LA-ICP-IDMS calibration strategies. ${ }^{40,41}$ However, further investigations are necessary to increase the aerosol homogenization as well as to reduce or eliminate local inhomogeneous distributions in the solid samples. First, the application of Ar as carrier gas should be investigated since Ar was recently assumed to favor the aerosol homogenization during the transport period whereas He tends to form flow domains characterized by extreme changes of the gas velocity, which probably accounts for the appearance of inhomogeneous regions. ${ }^{37,50}$ On the other hand, different solid matrixes and alternative synthesis and homogenizing processes (e.g., a freeze-drying process with the solid spike slurry or using sol-gel processes ${ }^{51}$ ) will be investigated for the solid spike in order to study the influence of the matrix on the solid spike homogeneity and, therefore, on the accuracy and precision of in-cell fs-LA-ICP-IDMS results. The production of further enriched solid standards would be required to extend the applicability of the in-cell isotope dilution method to other matrixes such as metals, biominerals, carbonates, and glasses. In addition, further investigations are necessary to study the fundamental process of sample and spike isotopic mixing during in-cell fs-LA-ICP-IDMS. This might be achieved by isotope ratio

(50) Bleiner, D.; Bogaerts, A. J. Anal. At. Spectrom. 2006, 21, 1161-1174.

(51) Davis, W. C.; Christopher, S. J.; Turk, G. C. Anal. Chem. 2005, 77, 63896395. 
measurements using different ablation cell designs and different types of mass spectrometers (e.g., quadrupole and multicollector). Finally, concerning particle-size and SEM measurements, the results of this work reveal a need for more critical evaluation of the techniques used for particle-size distribution measurements, because of the simultaneous presence of spherical particles and agglomerates of similar particle diameters within the aerosol.

\section{ACKNOWLEDGMENT}

The authors acknowledge Thermo Fisher Scientific for providing the X Series II ICPMS employed in this work. Also, B.F. acknowledges the postdoctoral fellowship from the "Secretaria de Estado de Universidades e Investigacion” of the Spanish Ministry of Education and Science.

\section{SUPPORTING INFORMATION AVAILABLE}

Additional information as noted in text. This material is available free of charge via the Internet at http://pubs.acs.org. 